\title{
Diversity and Abundance of Pest Insects Associated with Solanum tuberosum L. 1753 (Solanaceae) in Balessing (West-Cameroon)
}

\author{
Babell Ngamaleu-Siewe, Boris Fouelifack-Nintidem, Jeanne Agrippine Yetchom-Fondjo, \\ Basile Moumite Mohamed, Junior Tsekane Sedick, Edith Laure Kenne, Biawa-Miric Kagmegni, \\ Patrick Steve Tuekam Kowa, Romaine Magloire Fantio, Abdel Kayoum Yomon, Martin Kenne*
}

Department of the Biology and Physiology of Animal Organisms, University of Douala, Douala, Cameroon

\section{Email address:}

babellngamaleu@yahoo.fr (B. Ngamaleu-Siewe), fouelifacknintidemboris@yahoo.fr (B. Fouelifack-Nintidem), jayetchomfondjo@gmail.com (J. A. Yetchom-Fondjo), moumite@yahoo.fr (B. Moumite Mohamed), stsekane@yahoo.com (S. J. Tsekane), edithlaure.kenne@yahoo.fr (E. L. Kenne), biawamiric@gmail.com (Biawa-Miric K.), tukopast@gmail.com (P. S. T. Kowa), fantioromainemagloire12@yahoo.com (R. M. Fantio), abdelkayoumyomon@yahoo.fr (A. K. Yomon), medoum68@yahoo.fr (M. Kenne), martin.kenne@univ-douala.cm (M. Kenne)

${ }^{*}$ Corresponding author

\section{To cite this article:}

Babell Ngamaleu-Siewe, Boris Fouelifack-Nintidem, Jeanne Agrippine Yetchom-Fondjo, Basile Moumite Mohamed, Junior Tsekane Sedick, Edith Laure Kenne, Biawa-Miric Kagmegni, Patrick Steve Tuekam Kowa, Romaine Magloire Fantio, Abdel Kayoum Yomon, Martin Kenne. Diversity and Abundance of Pest Insects Associated with Solanum tuberosum L. 1753 (Solanaceae) in Balessing (West-Cameroon). American Journal of Entomology. Vol. 5, No. 3, 2021, pp. 51-69. doi: 10.11648/j.aje.20210503.13

Received: July 14, 2021; Accepted: August 3, 2021; Published: August 11, 2021

\begin{abstract}
Solanum tuberosum L. 1753 (Solanaceae) is widely cultivated for its therapeutic and nutritional qualities. In Cameroon, the production is insufficient to meet the demand in the cities and there is no published data on the diversity of associated pest insects. Ecological surveys were conducted from July to September 2020 in 16 plots of five development stages in Balessing (WestCameroon). Insects active on the plants were captured and identified and the community structure was characterized. The abundance of each species and the part of the plant attacked were recorded. A total of 370 specimens belonged to four orders, 16 families and 21 species. From rearings of 3,200 scarified stems and tubers, two Lepidoptera emerged: the Crambidae Leucinodes orbonalis Guenee, 1854 (18.0\%) and the Noctuidae Helicoverpa armigera Hübner, 1808 (26.0\%). This gives a total of five orders, 18 families and 23 species associated with the potato plants. We recorded $16(69.6 \%)$ pest species [10 (43.5\%) non-native and six (26.1\%) native species]. Base on the family composition, Coleoptera and Hemiptera were mostly represented (31.3\% respectively) followed by Orthoptera (25.0\%) and Diptera (12.4\%). Based on the species composition, Hemiptera presented a high number of species (38.1\%) followed by Coleoptera (28.6\%), Orthoptera (23.8\%) and Diptera (9.5\%). Based on abundances, Aphididae (60.6\%) was the most represented, followed by Gryllotalpidae (7.6\%), Tenebrionidae (6.5\%), Bibionidae (5.7\%), Gryllidae (4.9\%), Pentatomidae (4.9\%), Cicadellidae (3.5\%) and Pyrgomorphidae (2.4\%). Eight rare families were recorded $(<1 \%$ of the total collection respectively) (Acrididae, Chrysomelidae, Elateridae, Lycidae, Scarabeidae, Scutelleridae, Tipulidae and Pyrrhocoridae). Chemicals were not efficient in the study locality, since entomofauna associated with potato plants remained diverse and consisted of alien pests. The situation calls for more research on the bio-ecology of the recorded pests with further goal of developing sustainable management strategies to reduce yield losses.
\end{abstract}

Keywords: Solanum tuberosum, pest insects, Biodiversity, Balessing (Cameroon)

\section{Introduction}

The potato Solanum tuberosum L., 1753 (Solanaceae) is one of the most cultivated plants. Tubers are mostly consumed in the world [1-3]. In African countries the production is low compared to the situation in developing countries although nowadays, the adaptability of this crop to a wide range of environmental conditions is known [4-6]. The overall production is insufficient 
to meet the ever-increasing demand in the cities. Causes of low productions are not fully known. But available information from Ethiopia and Cameroon points out the sex and education level of farmers, improved varieties, insufficient use of fertilizers, inexperience of farmers, access to extension, harvesting time, soil conservation, nature of access to land, access to market, access to irrigation schemes, inadequate phytosanitary control, unsuitability of agricultural policies, low soil fertility, the use of infested planting material, high disease and pest infection rates, losses during storage including losses in quality [7-9]. Potato plant organs are target of several attacks such as microorganisms (fungi, viruses and bacteria) and metazoan organisms (phytophagous and xylophagous agents). Several animal species use them either as a nesting site (e.g. insects that drill stems and tubers such as larvae of beetles, wasps that can build their nests at the bottom of the leaves), or as a feeding site and thus as a foraging site (termites that rob the plant from the roots, nectarivorous insects including adults of ants and butterflies who feed on sweet liquids secreted by the plant), or both as nesting and feeding site (cases of Hemipterans such as aphids and mealy bugs that pump the plant's sap to exploit proteins and a little sugar and discard the remaining enriched sugar called honeydew [10]. When Insects feed on plant organs, the saliva injected during food intake can be toxic to the plant as it is the case with Thrips [11]. Then these insects directly damage the plants and indirectly cause the drastic decrease that affect productivity of the attacked plants $[12,13]$. The lack of yielding amendment and high quality of seed potato tubers and absence of resistance to pests and diseases, are known as problems for the cultivation of potato in Cameroon [14]. Studies on the entomofauna associated with potato plants have been conducted in Bangladesh, Pakistan, Sudan and Côte d'Ivoire where authors pointed out the negative effect of insect pests [10, 12-15]. Although potatoes are cultivated in Cameroon, no published data exist on the diversity of associated insects. However the control of pest insects is one of the major constraints to be overcome in potato cultivation. Chemical treatments are usually recommended for the eradication of target enemies of crops. In the rural area of Balessing (West-Cameroon), market gardening activities are on the rise, but they are practiced by young farmers, little educated, unassisted and each having a fairly low income. Physical damages are recorded in chemically treated plantations. The purpose of this study is to identify insects active on potato plants, to characterize the community structure and damages.

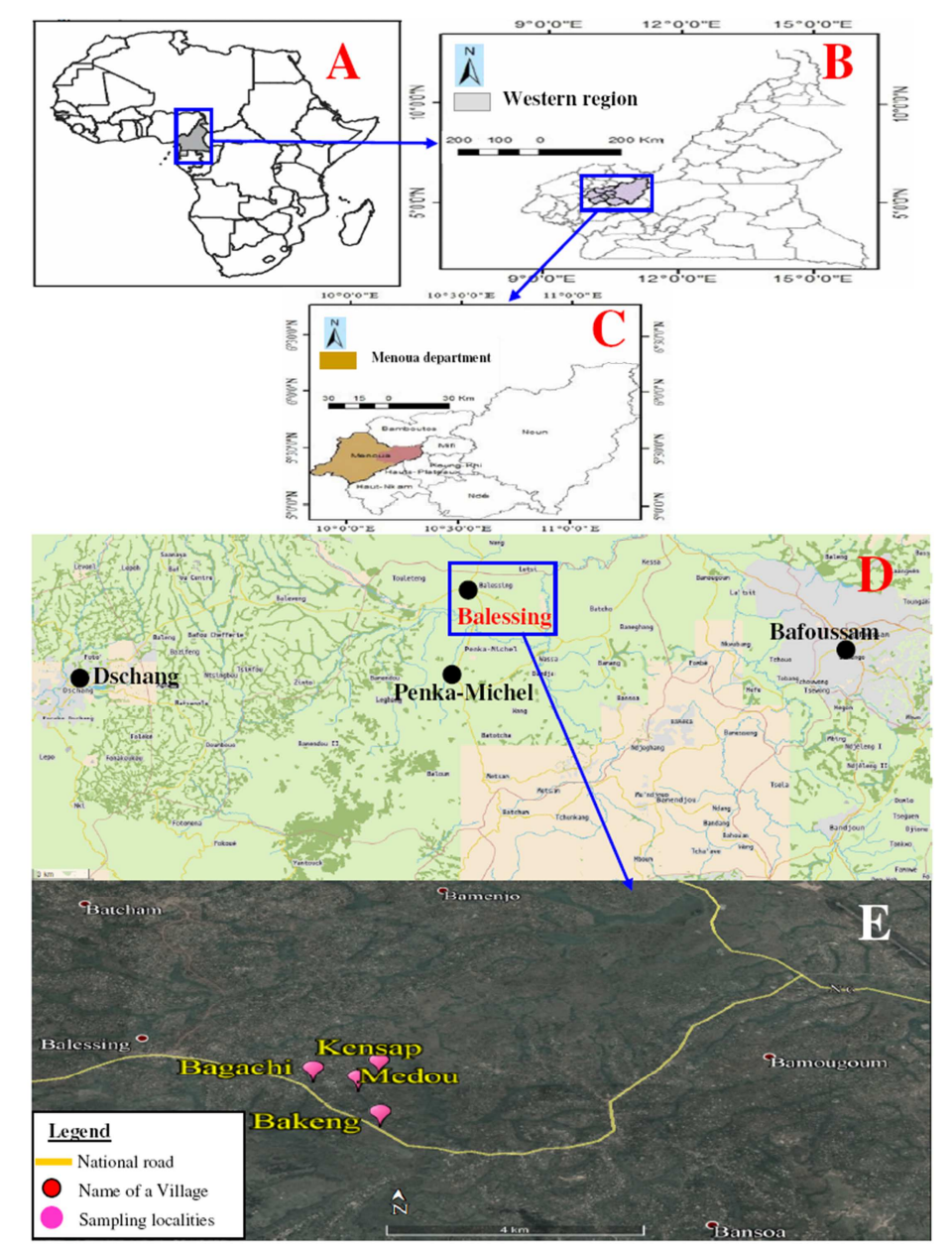

Figure 1. Location of the study locality in Cameroon. A, B and C: Location of Menoua Department in the Western region of Cameroon (adapted from Abossolo et al. [16]), D: Location of Balessing village between Dschang and Bafoussam; E: Location of the sampling sites. 


\section{Materials and Methods}

\subsection{Study Sites}

Field investigations were conducted during the rainy season (July to September 2020) in Balessing $\left(5^{\circ} 30^{\prime} 4.15^{\prime \prime} \mathrm{N}\right.$, $10^{\circ} 14^{\prime} 30.70^{\prime \prime} \mathrm{E}$; altitude: $1,442 \mathrm{~m}$ a.s.l) situated in the Western region of Cameroon (Figure 1). Field observations were set up in 16 plots located in four localities (Figure 1): Bagachi $\left(5^{\circ} 29^{\prime} 35.41^{\prime \prime} \mathrm{N}, 10^{\circ} 15^{\prime} 51.58^{\prime \prime} \mathrm{E}\right.$; altitude: $1,428 \mathrm{~m}$ a.s.l), Bakeng $\left(5^{\circ} 28^{\prime} 52.87^{\prime \prime} \mathrm{N}, 10^{\circ} 16^{\prime} 28.86^{\prime \prime} \mathrm{E}\right.$; altitude: 1,406 $\mathrm{m}$ a.s.l), Kensap $\left(5^{\circ} 29^{\prime} 43.09^{\prime \prime} \mathrm{N}, 10^{\circ} 16^{\prime} 26.94^{\prime \prime} \mathrm{E}\right.$; altitude: $1,398 \mathrm{~m}$ a.s.l), and Medou $\left(5^{\circ} 29^{\prime} 26.81^{\prime \prime} \mathrm{N}, 10^{\circ} 16^{\prime} 16.20^{\prime \prime} \mathrm{E}\right.$; altitude: $1,417 \mathrm{~m}$ a.s.l). Balessing is situated $21 \mathrm{~km}$ from Dschang (Menoua Department) and $31 \mathrm{~km}$ from Bafoussam (Mifi Department) (Figure 1) and vegetables are grown in lowlands [16]. The prevailing climate is humid tropical subequatorial of high altitude and is classified as "Aw" by Köppen and Geiger [17]. Two seasons of unequal duration are described: a long rainy season of eight months (midMarch to mid-November with the peak of rains in AugustSeptember) and a short dry season of four months (midNovember to mid-March) $[18,19]$. The soil is hydromorphic type at lowlands and sandy-clay or ferralitic type in higher areas. The vegetation is dominated by food crops and market gardens.

\subsection{Sample Design}

Potato plants were categorized into six development stages; stage 1 plant was seedlings obtained nine days after planting of tubers, stage 2 plant (St2) was observed 30 to 40 days after planting of tubers and was characterized by the development of leaves and the progressive lengthening of the stem, stage 3 plant (St3) was observed after 50 to 60 days of maintenance and were characterized by the appearance of flowers and tubers (the peak of flowering is observed 60 to 80 days from the planting date), stage 4 plant (St4) was characterized by the appearance of the last flowers and the intense development of tubers, stage 5 plant (St5) was that of intense tuber growth (observed after 70 to 90 days of maintenance), and stage 6 plant (St6) was observed after 85 to 130 days of maintenance and was characterized by the senescence of leaves, stems and the stopping development of tubers. In four localities of the village, we randomly selected 16 farmers who granted us access and control in their plots. Sixteen plots of St2 to St6 were categorized into six unmaintained plots and 10 well-maintained plots. Unlike well-maintained plots, unmaintained plots were weeded. The unmaintained plots contained St6 plants.

The study localities were subjected to the same climate. The plot surface varied from 40 to $500 \mathrm{~m}^{2}\left(191.6 \pm 34.0 \mathrm{~m}^{2}\right.$; 16 plots) and consisted of 108 to 410 plants (234 \pm 20 plants; one to three plants $/ \mathrm{m}^{2}$ ). At least three-meter space separated plots from neighbouring fallows and plots of subsistence farming. In each locality, plots were separated from each other by a distance of 10 to $500 \mathrm{~m}(116.8 \pm 41.9 \mathrm{~m}, 16$ plots $)$.
Potatoes were planted in rows and for each row, the gap between two neighbouring plants varied from 0.7 to $1.2 \mathrm{~m}$ ( $0.97 \pm 0.16 \mathrm{~m} ; 2468$ seedlings). Based on the development stages of plants, plots were divided into six categories: two plots of St2 plants $\left(120\right.$ and $180 \mathrm{~m}^{2}, 150.0 \pm 30.0 \mathrm{~m}^{2}, 260$ and 274 plants, $267 \pm 7$ plants, two plants $/ \mathrm{m}^{2}$ ), four plots of $\mathrm{St} 3$ plants (40 to $375 \mathrm{~m}^{2}, 196.3 \pm 68.7 \mathrm{~m}^{2}, 108$ to 340 plants, $215 \pm 48$ plants, one plant $/ \mathrm{m}^{2}$ ), three plots of St 4 plants ( 75 to $210 \mathrm{~m}^{2}, 140.0 \pm 39.1 \mathrm{~m}^{2}, 135$ to 284 plants, $203 \pm 44$ plants, one plant $/ \mathrm{m}^{2}$ ), five plots of St5 plants (60 to $500 \mathrm{~m}^{2}$, $262.0 \pm 90.2 \mathrm{~m}^{2}$, 135 to 410 plants, $255 \pm 48$ plants, one plant $\left./ \mathrm{m}^{2}\right)$ and two plots of St6 plants $\left(100\right.$ and $150 \mathrm{~m}^{2}$, $125.0 \pm 25.0 \mathrm{~m}^{2}, 186$ and 272 plants; $229 \pm 43$ plants, two plants $/ \mathrm{m}^{2}$ ). Farmers carried out 21 days after planting, one to two early chemical treatments applied on St2 plants. Chemical treatments were done between 7 and 9 a.m. and/or between 12 and 5 p.m., some treatments being carried out during the hottest hours of the day (from 12 to 2 p.m.). Chemical treatments were conducted using two categories of chemicals approved in Cameroon and usually used by farmers [20-24]: insecticides [Cigogne 50EC 494/09/IN (Cypermethrin $50 \mathrm{~g} / \mathrm{l}, 750 \mathrm{ml}$ p.c/ha), and Parastar 40EC 535/10/IN (20 g/1 Imidacloprid and $20 \mathrm{~g} / 1$ lamda-cyhalothrin, one 1 p.c./ha)] and fungicides [Kozeb $80 \mathrm{WP} 754 / 12 / \mathrm{FO}$ or Penncozeb 80WP 472/08/FO which are dispersible concentrates of Mancozeb $800 \mathrm{~g} / \mathrm{kg}$ (Dithiocarbonate, dosage: $1.7-2.5 \mathrm{~kg} / \mathrm{ha}$ )]. After the last chemical treatment, we cleared the plots during one week, of all scarified stems, damaged flowers and leaves. Capture of insects began the $14^{\text {th }}$ day after planting and continued until the harvest of tubers. Plants were inspected during two days a week from 7 a.m. to 3 p.m. each day and insects found on stems, branches, leaves and flowers, were captured using brushes for small insects or soft forceps for large non-flying insects or a vacuum cleaner. Flying insects were sampled using a sweep net or after neutralizing them using an aerosol insecticide spray. Adults of butterflies were conserved in A4 size paper devices folded to keep the wings intact while other insect adults were kept in labelled vials containing $70^{\circ}$ alcohol. During the harvest period, insects found on tubers were collected. The scarified tubers were collected and checked every day in laboratory until the release of adult insects. Butterfly caterpillars and other insect larvae were collected and reared in laboratory.

\subsection{Damage to Aerial Plant Organs}

Damage was assessed two days a week and described based on visual inspection. Damage on leaves and stems, and the number of healthy organs, were noted. A sample of 10 damaged stems (recognized by perforations or black scarring spots) was taken in each plot and monitored in the laboratory until the emergence of adult borers. During the harvest period, tubers were inspected and those showing signs of attack by the insects were collected and split to check for the presence of larvae and were placed in the laboratory until the adult's emergence. 


\subsection{Laboratory Rearing}

Rearing materials consisted of plastic containers (diameter: $37 \mathrm{~cm}$; deep: $12 \mathrm{~cm}$ ) covered with a fine-mesh fabric netting for natural ventilation. Samples of damaged stems separately placed in labelled rearing containers. Only one type of plant organ was placed in one container. In each container, 10 pieces of damaged stems or 10 damaged tubers were reared in laboratory ( 3,200 reared samples in 320 plastic containers: 1,600 pieces of stems in 160 plastic containers and 1,600 tubers in 160 other plastic containers). Samples of plant organs were first placed on sterilized sand and two weeks later, the sand was sieved in order to collect pupae. Collected pupae were placed on cotton wool soaked in water until the emergence of insect adults. Caterpillars from the field were collected with a sample of leaves of the supporting plant and placed in the laboratory on a young potato plant transplanted in pots and watered daily. Rearing pots were checked every day and emerged insect adults were kept and stored in labelled tubes containing $70^{\circ}$ alcohol. Emerged butterflies were kept in folded A4 size paper devices for identification.

\subsection{Identification of Insect Specimens}

Specimens were identified to the species level using appropriate keys [25-31] and confirmed by referring to illustrated catalogues and check lists [32-34]. In order to consider recent developments in the taxonomy of identified species and their native range, we consulted available reports [35-71].

\subsection{Statistical Analysis}

Numbers of species by order, family and genera were determined and percentages were calculated from the overall total specimens. Abundance counts were presented in terms of mean \pm se. Simultaneous comparison of several abundance series was set up using the Kruskal-Wallis test from SigmaStat software $2.0 \AA$ and the pairwise comparison was set up when relevant using Dunn's procedure because when considering the number of ant species as a metric/response variable, sample units being different, uneven variability could occur between sampling sites. Regression equation was set up and tested using ANOVA procedure. Two frequencies were compared using the Fisher's exact-test. For the whole orders, families and species distributions, simultaneous comparison was set up using the Fisher-Freeman-Halton exact-test from StatXact software 3.1, which is one of the best procedure recommended for nonparametric analysis of unordered contingency tables (our situation) and appropriate probabilities were adjusted for the number of simultaneous tests using the sequential Bonferroni procedure summarized by Rice [72].

A total of 14 indexes were determined using PAST 3.05 software: the abundance of the $\mathrm{i}^{\text {th }}$ species $\mathrm{n}_{\mathrm{i}}$, the sample size $\mathrm{n}$, the maximum abundance, the observed species richness $\mathrm{S}$, Margalef's index, the richness ratio, Shannon-Weaver's index, Simpson's index, Hill's number one index $\mathrm{N}_{1}$, Hill's number two index $\mathrm{N}_{2}$, Hill diversity ratio, Pielou's index J,
Hill's evenness index, and Berger-Parker's index. Comparison of the species richness was performed using the individual rarefaction procedure. The non parametric estimation Chao 1 was used to estimate the theoretical species richness $\mathrm{T}$ and the sampling effort was estimated as (S/T)x100.

The overall species covariance was evaluated using Schluter's procedure [73]. Between species correlations was evaluated using Kendall's tau coefficient. The dissimilarity between plots and between plant stages was evaluated using Bray-Cutis's index and was confirmed using the classical Hierarchical Cluster Analysis based on Jaccard's similarity index. The cluster was constructed using UPGMA algorithm [74].

The rank abundance plotting was used to illustrate the shape of the SADs and the goodness of fit of each SAD to a theoretical model was assessed by calculating the Pearson's correlation coefficient and interpreting as summarized by Biawa-Kagmegni et al. [75]. We tested five commonly used theoretical SADs [76] to fit our curves: the Broken-stick model (BS), the Geometric model (GM), the Lognomal model (LM), the Zipf model (Z) and the Zipf-Mandelbroot model (ZM). The best fitted model was selected using AIC procedure summarized by Johnson and Omland [77]. The package vegan of R 3.4.1 software [78] helped us to adjust the SADs. BS model has a single parameter $\mathrm{x}$ which represents the mean abundance of species [79]. We determined the parameters of GM or LM on which the studied insects' communities depended. GM depends on the maximum abundance of the first-rang species $n_{1}$ and the Motomura's environment constant $\mathrm{m}$. The $\mathrm{m}$ parameter gives the decay rate of the abundance per rank [80]. $\mathrm{Z}$ model is based on the ZL [81], abundances being ranked in decreasing order. $\mathrm{Z}$ model is based on two statistics: $\mathrm{Q}$ is the scaling parameter (normalizing constant), and $\gamma$ (gamma) is the decay coefficient or the average probability of the appearance of a species [81, 82]. ZM is a generalized model in which $\beta$ (beta) is added. Marquardt's nonlinear least squares algorithm summarized by Le et al. [83] and Murthy [84], was used to estimate $\beta$ and $\gamma$. We calculated $1 / \gamma$ (fractal dimension of the distribution of individuals among species) $[85,86]$.

\subsection{Abbreviations}

a.s.l: above sea level, AIC: Akaike Information Criteria, $A g$. (Agriotes) lineatus: Agriotes (Agriotes) lineatus Linnaeus, 1767, An. notatus: Anacatantops notatus Karsch, 1891, Au. solani: Aulacorthum solani Kaltenbach, 1843, As. armigera: Aspavia armigera Fabricius, 1775, B. anglicus: Bibio anglicus Verrall, 1869, BC: Bray-Curtis dissimilarity index, BS: Broken-stick model, C. discrepans: Calopteron discrepans Newman, 1838, Chao 1: Chao's Abundance based nonparametric estimators of the species richness, d: Richness ratio, D: Simpson index, D. voelkeri: Dysdercus voelkeri Schmidt, 1932, df: degree of freedom, Em. fabae: Empoasca fabae Harris 1841, E $\left(\mathrm{S}_{\mathrm{n}}\right)$ : expected species richness for a theoretical sample of n individuals, Eu. fulgida fulgida: Euphoria fulgida fulgida Fabricius, 1775, GM: Geometric series model, Gr. 
(Gryllus) campestris: Gryllus (Gryllus) campestris Linnaeus, 1758, Gy. gryllotalpa: Gryllotalpa gryllotalpa Linnaeus, 1758, $\mathrm{I}_{\mathrm{BP}}$ : Berger-parker dominance index, J: Pielou evenness index, H: Kruskal-Wallis test, H': Shannon-Weaver's diversity index, H. armigera: Helicoverpa armigera Hübner, 1808, La. hirta: Lagria hirta Linnaeus, 1758, Le. orbonalis: Leucinodes orbonalis Guenee, 1854, LM Lognormal model, Lo. quadriguttatus: Longitarsus quadriguttatus Pontopidan, 1763, m: Motomura's environment constant, Ma. euphorbiae: Macrosiphum euphorbiae Thomas, 1878, Mg: Margalef's richness index, My. persicae: Myzus persicae Sulzer, 1776, N. viridula: Nezara viridula Linnaeus, 1758, $\mathrm{n}_{\mathrm{i}}$ : absolute abundance of species I, $\mathrm{N}_{1}$ : Hill's number one index, $\mathrm{N}_{2}$ : Hill's number two index, p: statistical probability, $P$. (Phymelloides) vignaudii: Pyrgomorpha (Phymelloides) vignaudii GuerinMeneville, 1847, Q: scaling parameter also called the normalizing constant, S: species richness (total number of species), SAD; Species Abundance Distribution, Sp. annulus: Sphaerocoris annulus Fabricius, 1775, Sy. frontalis: Systena frontalis Fabricius, 1801, r: Pearson's correlation coefficient, $\mathrm{r}_{\mathrm{s}}$ : Spearman's correlation coefficient, $r^{2}$ : linear regression's coefficient of determination, se: standard error, St2: development stage 2 plants, St3: development stage 3 plants, St4: development stage 4 plants, St5: development stage 5 plants, St6: development stage 6 plants; $\tau$ : Kendall's tau correlation, T: Theoretical species richness, Ta. calliparea: Taphronota calliparea Schaum, 1853, Ti. paludosa: Tipula paludosa Meigen, 1830, UPGMA: Unweighted Pair Group Method with Arithmetic mean algorithm, VR: Schluter's Variance ratio, Z: Zipf model, ZL: Zipf's Law, ZM: ZipfMandelbroot model, $\alpha$ ': Bonferroni adjusted significance level, $\beta$ (beta): the degree of the niche diversification, $\gamma$ (gamma): decay coefficient or the average probability of the appearance of a species, $\chi^{2}$ : chi-square statistic.

\section{Results}

\subsection{Insects Associated with Potato Plants}

Insects collected in the field belonged to four orders (Coleoptera Linnaeus, 1758, Diptera Linnaeus, 1758, Hemiptera Linnaeus, 1758 and Orthoptera Latreille, 1793) and 16 families (Table 1).

Table 1. Absolute and relative abundance of the collected Insects and the damaged plant organs.

\begin{tabular}{|c|c|c|c|c|c|c|c|c|}
\hline ORDER / Family & Specie's name & Status & Origin & Reference & Plant organs & I (\%) & II (\%) & III (\%) \\
\hline \multicolumn{9}{|c|}{ COLEOPTERA } \\
\hline Chrysomelidae & Systena frontalis Fabricius, 1801 & *, pest & $\mathrm{NE}(\mathrm{CA}, \mathrm{EA})$ & [34-39] & Leave & $1(0.3)$ & - & $1(0.3)$ \\
\hline Elateridae & Agriotes (Agriotes) lineatus Linnaeus, 1767 & $\#$, pest, in & $\mathrm{HO}$ & {$[40-42]$} & Tuber, tuber & - & $1(0.3)$ & $1(0.3)$ \\
\hline Lycidae & Calopteron discrepans Newman, 1838 & * & NE (EA) & [43] & Leave & - & $2(0.5)$ & $2(0.5)$ \\
\hline Scarabaeidae & Euphoria fulgida fulgida Fabricius, 1775 & * & $\mathrm{NE}$ & [44] & Leave & - & $1(0.3)$ & $1(0.3)$ \\
\hline \multirow[t]{2}{*}{ Tenebrionidae } & Lagria hirta Linnaeus, 1758 & $\S$ & $\mathrm{HO}(\mathrm{WP})$ & {$[45-47]$} & Leave, flower & $5(1.4)$ & $18(4.9)$ & $23(6.2)$ \\
\hline & Longitarsus quadriguttatus Pontopidan, 1763 & * & $\mathrm{HO}(\mathrm{WP})$ & {$[48]$} & Leave & $1(0.3)$ & - & $1(0.3)$ \\
\hline \multicolumn{9}{|l|}{ DIPTERA } \\
\hline Bibionidae & Bibio anglicus Verrall, 1869 & $?$ & $\mathrm{HO}$ & {$[30]$} & Leave & $8(2.2)$ & $13(3.5)$ & $21(5.7)$ \\
\hline Tipulidae & Tipula paludosa Meigen, 1830 & $\#$, pest, in & NE (NA) & [49] & Leave & - & $1(0.3)$ & $1(0.3)$ \\
\hline \multicolumn{9}{|l|}{ HEMIPTERA } \\
\hline \multirow[t]{3}{*}{ Aphididae } & Aulacorthum solani Kaltenbach, 1843 & $\S$, pest, in & HO (PA) & {$[26,50-52]$} & Leave & $34(9.2)$ & $30(8.1)$ & $64(17.3)$ \\
\hline & Macrosiphum euphorbiae Thomas, 1878 & $\S$, pest, in & NE (NA) & {$[51,53]$} & Leave & $22(6.0)$ & $28(7.6)$ & $50(13.5)$ \\
\hline & Myzus persicae Sulzer, 1776 & $\S$, pest & WWC, HO (PA) & {$[52,54,55]$} & Flower, leave & $54(14.6)$ & $58(15.7)$ & $112(30.3)$ \\
\hline Cicadellidae & Empoasca (Empoasca) fabae Harris 1841 & $\S$, pest, in & NE (TA, STA) & {$[56]$} & Leave, stem & $4(1.1)$ & $9(2.4)$ & $13(3.5)$ \\
\hline \multirow[t]{2}{*}{ Pentatomidae } & Aspavia armigera Fabricius, 1775 & $\S$, pest & $\mathrm{AF}$ & {$[57-59]$} & Leave, stem & $1(0.3)$ & $7(1.9)$ & $8(2.2)$ \\
\hline & Nezara viridula Linnaeus, 1758 & $\S$, pest & WWC, AF & {$[60,61]$} & Leave & $3(0.8)$ & $7(1.9)$ & $10(2.7)$ \\
\hline Pyrrhocoridae & Dysdercus voelkeri Schmidt, 1932 & $\S$, pest & AF, PANT & [57] & Leave & $2(0.5)$ & - & $2(0.5)$ \\
\hline $\begin{array}{l}\text { Scutelleridae } \\
\text { ORTHOPTERA }\end{array}$ & Sphaerocoris annulus Fabricius, 1775 & $\S$, pest & $\mathrm{AF}$ & [57] & Leave & $2(0.5)$ & - & $2(0.5)$ \\
\hline Acrididae & Anacatantops notatus Karsch, 1891 & * & $\mathrm{AF}$ & {$[28,62-64]$} & Leave & $1(0.3)$ & $2(0.5)$ & $3(0.8)$ \\
\hline Gryllidae & Gryllus (Gryllus) campestris Linnaeus, 1758 & * & HO (NWP) & [65] & Tuber, tuber & - & $18(4.9)$ & $18(4.9)$ \\
\hline Gryllotalpidae & Gryllotalpa gryllotalpa Linnaeus, 1758 & * & $\mathrm{HO}$ & {$[66,67]$} & Tuber, tuber & - & $28(7.6)$ & $28(7.6)$ \\
\hline \multirow[t]{2}{*}{ Pyrgomorphidae } & $\begin{array}{l}\text { Pyrgomorpha vignaudii Guerin-Meneville, } \\
1847\end{array}$ & *, pest & $\mathrm{AF}$ & [29, 31, 62- & Leave & $2(0.5)$ & - & $2(0.5)$ \\
\hline & $\begin{array}{l}\text { Taphronota (Taphronota) calliparea } \\
\text { Schaum, } 1853\end{array}$ & $*$ & $\mathrm{AF}$ & {$[28,62-64]$} & Leave & $1(0.3)$ & $6(1.6)$ & $7(1.9)$ \\
\hline Sample size & & & & & & $141(38.1)$ & $229(61.9)$ & $370(100)$ \\
\hline
\end{tabular}

I to III see table $1 ; *=$ phytophagous; \#=stem-borer or root-feeding; $\S=$ sap feeding; ?=unknown pest status; in=invasive species; pest=pest species; -=not recorded; $\mathrm{CA}=$ Central America; $\mathrm{EA}=$ Eastern America; $\mathrm{AF}=$ Tropical Africa; $\mathrm{HO}=$ Holarctic region; WWC $=$ Worldwide cosmopolitan species; $\mathrm{NA}=\mathrm{Northern}$ America; NE=Neartic region; NWP=North-Western Palaearctic region; PA=Palaearctic region; TA=Tropical America; $\mathrm{STA}=\mathrm{Subtropical}$ America; PANT=Pantropical distribution; $\mathrm{WP}=$ Western Palearctic region.

Insects from the laboratory rearing belonged to one order (Lepidoptera Linnaeus, 1758), and two families (Crambidae Latreille, 1810 and Noctuidae Latreille, 1809). This gives a total of five orders and 18 families that have been recorded.
The variation in percentages was globally significant in the field collection (asymptotic Pearson's chi-square: $\chi^{2}=218.07$, $\mathrm{df}=12, \mathrm{p}<0.001)$. This was also the situation in wellmaintained plots (Fisher-Freeman-Halton test: $\chi^{2}=19.65$, 
$\mathrm{df}=9, \mathrm{p}=0.020)$ and in unmaintained plots $\left(\chi^{2}=170.00, \mathrm{df}=3\right.$, $\mathrm{p}<0.001$ ).

Two species (8.7\% respectively) emerged from 3,600 laboratory rearings: one species of Crambidae (4.3\%) (Leucinodes orbonalis Guenee, 1854) (23 cases, $0.7 \%)$ and one species of Noctuidae (4.3\%) (Helicoverpa armigera Hübner, 1808) (102 cases, 3.2\%). No insect emerged from 3,075 organs $(96.1 \%)$.

A total of 370 specimens collected in the field corresponded to 21 genera and 21 species (Table 1). Overall the variation of the percentages was significant (Pearson's chi-square: $\left.\chi^{2}=496.01, \mathrm{df}=80, \mathrm{p}<0.001\right)$ and the same was true for well-maintained plots $\left(\chi^{2}=111.10, \mathrm{df}=42, \mathrm{p}=3.7 \times 10^{-8}\right)$ and unmaintained plots $\left(\chi^{2}=229.00, \mathrm{df}=15, \mathrm{p}<0.001\right)$. We identified one species of Acrididae (4.3\%) (Anacatantops notatus Karsch, $1891,0.8 \%$ of the total collection), three species of Aphididae (13.0\%) (17.3\% of Aulacorthum solani Kaltenbach, $1843,13.5 \%$ of Macrosiphum euphorbiae Thomas, 1878, and 30.3\% of Myzus persicae Sulzer, 1776). From the same collection we identified one species of Bibionidae (4.3\%) (Bibio anglicus Verrall, 1869, 5.7\% of the total collection), one species of Chrysomelidae (4.3\%) (Systena frontalis Fabricius, 1801, $0.3 \%$ of the total collection), one species of Cicadellidae (4.3\%) (Empoasca (Empoasca) fabae Harris 1841, 3.5\% of the total collection), one species of Elateridae (4.3\%) (Agriotes (Agriotes) lineatus Linnaeus, $1767,0.3 \%$ of the total collection). More over, we identified one species of Gryllidae (4.3\%) (Gryllus (Gryllus) campestris Linnaeus, $1758,4.9 \%$ of the total collection), one species of Gryllotalpidae (4.3\%) (Gryllotalpa gryllotalpa Linnaeus, $1758,7.6 \%$ of the total collection), one species of Lycidae (4.3\%) (Calopteron discrepans Newman, 1838, $0.5 \%$ of the total collection). Two species of Pentatomidae (8.7\%) were recorded (2.2\% of Aspavia armigera Fabricius, 1775 and $2.7 \%$ of Nezara viridula Linnaeus, 1758$)$. We also recorded two species of Pyrgomorphidae (8.7\%) $(0.5 \%$ of Pyrgomorpha vignaudii Guerin-Meneville, 1847 and $1.9 \%$ of Taphronota (Taphronota) calliparea Schaum, 1853), one species of Pyrrhocoridae (4.3\%) (Dysdercus voelkeri Schmidt, 1932, $0.5 \%$ of the total collection), one species of Scarabaeidae (4.3\%) (Euphoria fulgida fulgida Fabricius, $1775,0.3 \%$ of the total collection). We also identified one species of Scutelleridae (4.3\%) (Sphaerocoris annulus Fabricius, $1775,0.5 \%$ of the total collection), two species of Tenebrionidae (8.7\%) (6.2\% of Lagria hirta Linnaeus, 1758 and $0.3 \%$ of Longitarsus quadriguttatus Pontopidan, 1763) and one species of Tipulidae (4.3\%) (Tipula paludosa Meigen, $1830,0.3 \%$ of the total collection). The Aphididae species were the most represented (61.1\%), followed very far by the species of Gryllotalpidae (7.6\%), Tenebrionidae (6.5\%), Bibionidae (5.7\%), Pentatomidae and Gryllidae (4.9\% respectively). We also recorded Cicadelidae (3.5\%) and Pyrgomorphidae (2.4\%) while the species belonging to the remaining eight families (Acrididae, Chrysomelidae, Elateridae, Lycidae, Pyrgomorphidae, Scarabaeidae, Scutelleridae and Tipulidae) were rare $(<1 \%)$ (Table 1). No species was recorded exclusively on St2 plants. D. voelkeri and Lo. quadriguttatus were recorded exclusively on St3 plants. Sy. frontalis was recorded exclusively on St4 plants. C. discrepans, Eu. fulgida fulgida and Ti. paludosa were recorded exclusively on St5 plants. Ag. (Agriotes) lineatus, Gr. (Gryllus) campestris and Gy. gryllotalpa were recorded exclusively on St6 plants. An. notatus, As. armigera, P. vignaudii, Sp. annulus and Ta. (Taphronota) calliparea were recorded simultaneously on St4 and St5 plants. La. hirta was recorded simultaneously on St2, St 3 and St5 plants. $A u$. solani, B. anglicus, Em. (Empoasca) fabae, and $M a$. euphorbiae were recorded simultaneously on St2, St 4 and St5 plants. $N$. viridula was recorded simultaneously on St3 to St5 plants. My. persicae was recorded simultaneously on St2 to St5 plants. The species found exclusively on plants of a single stage of development (14.9\%) were significantly less abundant than those found on plants of several development stages (85.1\%) (Fisher exact test: $\chi^{2}=402.37, \mathrm{df}=1, \mathrm{p}=5.1 \times 10^{-}$ ${ }^{89}$ ) (Table 1).

Between the five plant development stages, the variation in species richness was significant (Fisher-Freeman-Halton test: $\left.\chi^{2}=20.23 ; \mathrm{df}=4 ; \mathrm{p}<0.001\right)$. Pairwise comparison showed significant difference between St 3 and St 5 plants $\left(\alpha^{\prime}=0.006\right.$, $\mathrm{p}=0.005)$ and between St5 and St6 plants $\left(\alpha^{\prime}=0.005\right.$, $\left.\mathrm{p}=4.0 \times 10^{-4}\right)$ while the difference was not significant between St4 and St6 plants $\left(\alpha^{\prime}=0.006, \mathrm{p}=0.009\right)$.

According to the cleanliness of the plots, five species (23.8\%) (D. voelkeri, P. (Phymelloides) vignaudii, Sp. annulus, Sy. frontalis, and Lo. quadriguttatus) were recorded exclusively in the well-maintained plots. Six other species (28.6\%) (Ag. (Agriotes) lineatus, C. discrepans, Eu. fulgida fulgida, Gr. (Gryllus) campestris, Gy. gryllotalpa, and Ti. paludosa) were recorded exclusively in the unmaintained plots. Ten species (47.6\%) (An. notatus, Au. solani, As. armigera, B. anglicus, Eu. fulgida fulgida, La. hirta, Ma. euphorbiae, My. persicae, $N$. viridula and Ta. calliparea) were recorded simultaneously in well-maintained and unmaintained plots (Table 1). This gives 23 species associated with potato plants. The species found exclusively in a single type of plots (15.9\%) were significantly less abundant than those found simultaneously in well-maintained and unmaintained plots (84.1\%) (Fisher exact test: $\chi^{2}=375.23, \mathrm{df}=1, \mathrm{p}=4.0 \times 10^{-83}$ ) (Table 1 ).

Based on the trophic behaviour of the insects, 11 phytophagous species were recorded: An. notatus, $D$. voelkeri, Em. fabae, Eu. fulgida fulgida, Gr. (Gryllus) campestris, Gy. gryllotalpa, C. discrepans, Lo. quadriguttatus, $P$. vignaudii, $S y$. frontalis and $T a$. (Taphronota) calliparea. Among these phytophagous insects D. voelkeri, Em. fabae, Gy. gryllotalpa, P. vignaudii and Sy. frontalis are known as pest species in cultivated areas. Two stem-borers or root-feeding species recorded (Ag. (Agriotes) lineatus and Ti. paludosa) are known as invasive species in introduced areas. In addition, insects that emerged from laboratory rearing (H. armigera and Le. orbonalis) are stemborers. Seven sap-feeding species were recorded (As. armigera, Au. solani, La. hirta, Ma. euphorbiae, My. persicae, $N$. viridula and $S p$. annulus) which are pests and 
invasive species except La. hirta. The harmful status of $B$. anglicus is unknown (Table 1).

According to the native range of the species, seven species (33.3\%) were native to Afrotropical region: An. notatus, As. armigera, D. voelkeri, $N$. viridula, $P$. vignaudii, Sp. annulus, and Ta. (Taphronota) calliparea. $N$. viridula is known as a worldwide cosmopolitan species while $D$. voelkeri is a pantropical distributed species. Eight species (38.1\%) were native to Holarctic region: Ag. (Agriotes) lineatus, Au. solani, B. anglicus, My. persicae, Gr. (Gryllus) campestris, Gy. Gryllotalpa, La. hirta and Lo. quadriguttatus. In addition $H$. armigera is native to central and southern Europe and Le. orbonalis is native to tropical and subtropical parts of Australia and Asia. Amongst the non-native species two Aphididae [Au. solani and My. persicae] are frequently reported in the Palaearctic region. Gryllidae Gr. (Gryllus) campestris is frequently found in the North-western Palaearctic region. Two Tenebionidae (La. hirta and Lo. quadriguttatus) are common in the Western Palaearctic region. Six species $(28.6 \%)$ are native to the Neartic region: C. discrepan, Em. faba, Eu. fulgida fulgida, Ma. euphorbiae, Sy. frontalis and Ti. paludosa. Amongst them the Lycidae $C$. discrepans is widely distributed in the Eastern America region. The Chrysomelidae Sy. frontalis is reported in central and Eastern America region. Aphididae Ma. euphorbiae and Tipulidae Ti. paludosa are widely distributed in the Northern America region. The Cicadellidae Em. fabae is distributed through out the tropical and subtropical America regions. Then sixteen alien species (69.6\%) were recorded. The percentage difference between alien and native species was not significant (Fisher's exact test: $\mathrm{p}=0.063$ ) (Table 1).

\subsection{Species Abundance}

A total of 370 specimens (18 \pm 6 specimens, 21 species) were collected in the field. These specimens were divided into 38 specimens $(6 \pm 2$ specimens, 6 species $)$ from plots of St 2 plants, 40 specimens ( $8 \pm 6$ specimens, 5 species) from plots of St 3 plants, 47 specimens ( $4 \pm 1$ specimens, 12 species $)$ from plots of St 4 plants, 198 specimens $(13 \pm 4$ specimens, 15 species) from plots of St5 plants and 47 specimens $(16 \pm 8$ specimens, 3 species) from plots of St6 plants. No specimen was recorded exclusively in plots of St2 plants. Three specimens $(0.8 \%)$ were collected exclusively in plots of St3 plants. One specimen $(0.3 \%)$ was collected exclusively in plots of St 4 plants. Four specimens (1.1\%) were collected exclusively in plots of St5 plants and 47 specimens (12.7\%) were recorded exclusively in plots of St6 plants. This makes a total of 55 specimens $(14.9 \%)$ recorded exclusively on a single development stage of the plants.

A total of 22 specimens $(5.9 \%)$ were recorded simultaneously in plots of St 4 and St 5 plants. We collected 23 specimens $(6.2 \%)$ simultaneously in the plots of St2, St 3 and St5 plants. A total of 10 specimens $(2.7 \%)$ were noted simultaneously in plots of St 3 to St5 plants. We collected 148 specimens $(40.0 \%)$ simultaneously in the plots of St2 to St5 plants. Finally 112 specimens $(30.3 \%)$ were recorded simultaneously in the plots of St2 to St5. This makes for cosmopolitan species, 315 specimens $(85.1 \%)$. Then species found exclusively on a single development stage of the plants were low represented than ubiquitous species (Fisher exact test: $\left.\chi^{2}=365.41 ; \mathrm{df}=1 ; \mathrm{p}=5.1 \times 10^{-89}\right)$. Species abundances varied significantly between the sample medians of the five development stages (Kruskall-Wallis multiple test: $\mathrm{H}=11.10$, $\mathrm{p}<0.001$ ) and the pairwise comparisons showed significant difference between $\mathrm{St} 3$ and $\mathrm{St} 5$ and between $\mathrm{St} 3$ and $\mathrm{St} 6$ (Dunn's test: $p<0.05$ respectively) while other comparisons were not significant). Percentages varied significantly between the five development stages (Fisher-Freeman-Halton test: $\left.\chi^{2}=345.73 ; \mathrm{df}=80 ; \mathrm{p}<0.001\right)$. Significant differences were noted for comparisons to plots of St5 plants [St2 plants $(10.3 \%)$ versus St3 plants $(10.8 \%)$ : $\alpha^{\prime}=0.025, \mathrm{p}=0.905$; St2 versus $\mathrm{St} 4$ plants $(12.7 \%): \alpha^{\prime}=0.008, \mathrm{p}=0.356$; St2 versus $\mathrm{St} 5$ plants (53.5\%): $\alpha^{\prime}=0.005, \mathrm{p}=1.9 \times 10^{-1.38}$; St2 versus St6 plants (12.7\%): $\alpha^{\prime}=0.010, \mathrm{p}=0.356$; St3 versus $\mathrm{St} 4: \alpha^{\prime}=0.013$, $\mathrm{p}=0.494$; St3 versus St5: $\alpha^{\prime}=0.056, \mathrm{p}=2.9 \times 10^{-37}$; St3 versus St6: $\alpha^{\prime}=0.017, \mathrm{p}=0.497$; St4 versus $\mathrm{St} 5: \alpha^{\prime}=0.007, \mathrm{p}=2.4 \times 10^{-33}$; St4 versus St6: $\alpha^{\prime}=0.005, \mathrm{p}=1.00$; St5 versus St6: $\alpha^{\prime}=0.006$, $\left.\mathrm{p}=2.4 \times 10^{-33}\right]$.

According to the cleanliness of the plots, no significant difference was noted between sample medians of the distribution in the well-maintained plots (141 and $9 \pm 4$ specimens; 15 species) and that noted in the unmaintained plots (229 and $14 \pm 4$ specimens; 16 species) (Kruskal-Wallis test: $\mathrm{H}=1.34 ; \mathrm{p}=0.241$ ) (Tables 1 and 2). Abundance difference was significant between well-maintained and unmaintained plots $\left(\chi^{2}=69.28, \mathrm{df}=20, \mathrm{p}<0.001\right)$.

Non-native species (336 specimens; $24 \pm 9$ specimens; 14 species i.e. $66.7 \%$ ) were highly represented than afrotropical native species (34 specimens; $5 \pm 1$ specimens; 6 species i.e. $28.6 \%$ ). There was a significant difference between sample medians (Kruskal-Wallis test: $\mathrm{H}=4.26 ; \mathrm{p}=0.027$ ).

\subsection{Communities'Structure}

Among the 5 categories of plant development stages, the species richness was very high in the plots of St5 plants (19 species, $71.4 \%$ of the overall species richness, Margalef's index: $M g=2.65$, Shannon-Weaver's index: $H^{\prime}=2.08$ ) while plots of St6 plants presented a lower one (three species, $\left.14.3 \%, \mathrm{Mg}=0.52, \mathrm{H}^{\prime}=0.76\right)$. The high value of Margalef's index was noted in plots of St4 plants (12 species, 57.1\%, $\left.\mathrm{Mg}=2.86, \mathrm{H}^{\prime}=1.84\right)$ and the low value was observed in plots of St6 plants. The species richness was high in the unmaintained plots ( 16 species, $76.2 \%, \mathrm{Mg}=2.76, \mathrm{H}^{\prime}=2.28$ ) and in the non-native species (14 species, $66.7 \%, \mathrm{Mg}=2.24$, $\left.\mathrm{H}^{\prime}=1.93\right)$ while it was low in the well-maintained plots $(15$ species, $\left.71.4 \%, \mathrm{Mg}=2.83, \mathrm{H}^{\prime}=1.82\right)$ and in the native species (7 species, 33.3\%, $\mathrm{Mg}=1.70, \mathrm{H}^{\prime}=1.74$ ) (Table 2). A low species richness was noted, values of the richness ratio being close to zero.

Based on the Chao 1 non-parametric estimator, the sampling success showed a very high score (100.0\%) respectively in plots of St 2 and St6 plants and in the native species. A lower score (42.2\%) was recorded in the plots of St4 plants. Low values of sampling efforts were noted in the 
well-maintained plots, the unmaintained plots and the nonnative species category $(85.7 \%, \quad 94.1 \%$ and $73.7 \%$ respectively) (Table 2).

The difference in diversity index was significant between well-maintained and unmaintained plots while it was not significant between native and non-native species categories. A low species diversity was recorded (Shannon-Weaver indexes were close to the median value while values of the Simpson's index were closed to zero except in plots of St5 plants). We noted a high even community and a low dominance by a few species (Table 2). The rank-abundance plotting of the pooled data presented a concave appearance suggesting the presence in the community of codominant species (Figure 2). The same shape of the graph was observed in well-maintained plots (Figure 3A), unmaintained plots (Figure 3B), native species (Figure 3C) and the nonnative species community (Figure 3D).

Based on the Hill's $\mathrm{N}_{2}$ index (Table 2) and the SAD plotting (Figure 3), and according to the plant development stages, four species codominated the St2 plants: Au. solani, B. anglicus, Ma. euphorbiae and My. persicae (Figure 3A). Two species codominated the St3 plants: La. hirta and My. persicae (Figure 3B). Four species codominated the St4 plants: Au. solani, Ma. euphorbiae, My. persicae and $N$. viridula (Figure 3C). Six species codominated the S5 plants: Au. solani, B. anglicus, Em. fabae, La. hirta, Ma. euphorbiae, and My. persicae (Figure 3D). Finally Gr. (Gryllus) campestris and Gy. gryllotalpa) co-dominated the community of St6 plants.

According to the cleanliness of the plots four species codominated the well-maintained plots: Au. solani, Ma. euphorbiae, My. persicae and La. hirta. Height species codominated the unmaintained plots: Au. solani, B. anglicus, Em. faba, Ma. euphorbiae, Gr. (Gryllus) campestris, Gy. Gryllotalpa, La. hirta and My. persicae.

According to the native origin, five species codominated the afrotropical species: An. notatus, As. armigera D. voelkeri, N. viridula, and Sp. annulus. Five other species codominated the non-native species: Au. solani, La. hirta, Ma. euphorbiae My. persicae and Gy. gryllotalpa. In short, six species codominated the global community: Au. solani, $B$. anglicus, Gy. gryllotalpa, La. hirta, Ma. euphorbiae and My. persicae (Figure 2).

Table 2. Matrix of the species richness, diversity, evenness and dominance indexes.

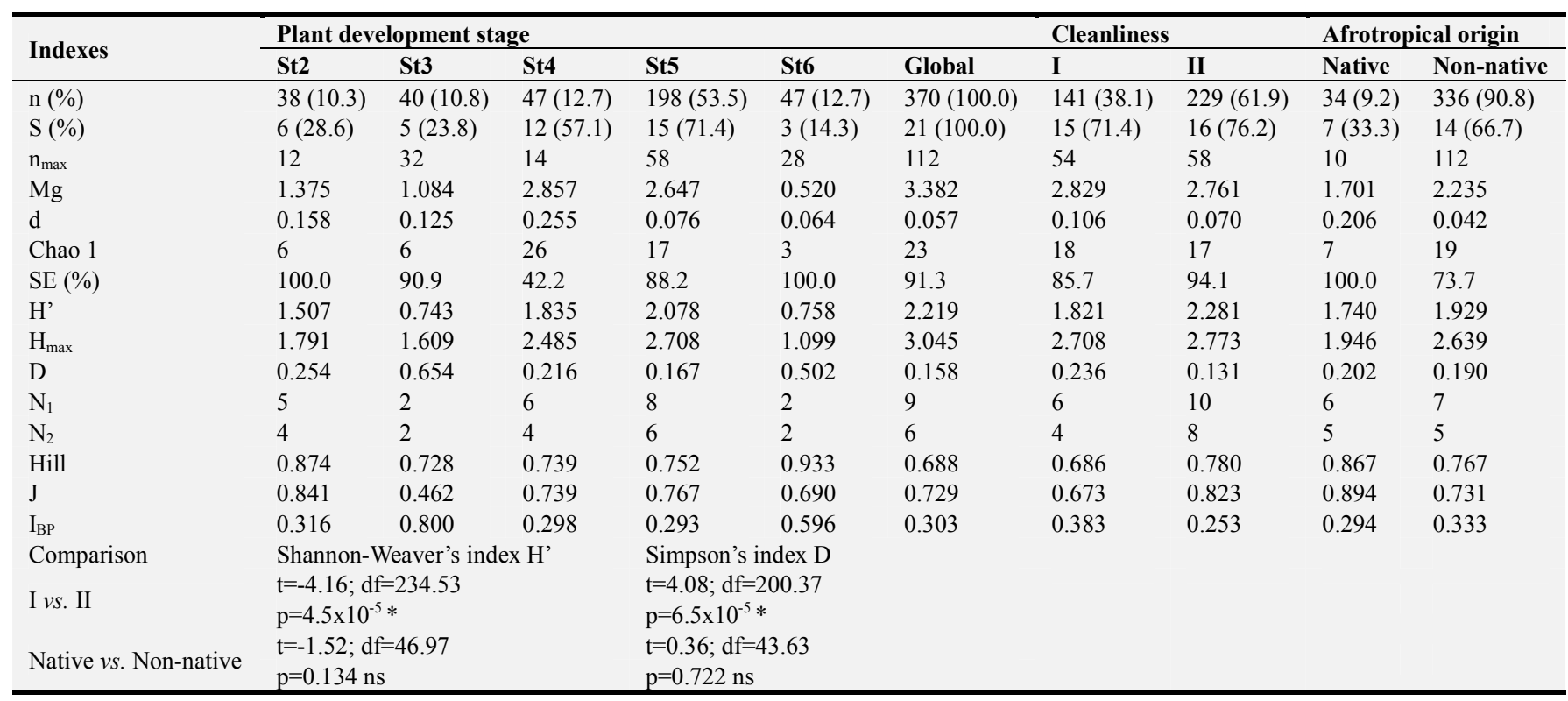

St2 to St6, *, I and II see table 1; n=sample size; $\mathrm{n}_{\max }=$ maximum abundance; $\mathrm{S}=$ observed species richness; Mg=Margalef's richness index; D=Simpson's diversity index; $d=$ =richness ratio; H'=Shannon-Weaver's diversity index; $\mathrm{H}_{\max }=$ Shannon-Weaver's maximum diversity index; J=Pielou's evenness index; $\mathrm{SE}=$ sampling effort; $\mathrm{N}_{1}=$ Hill's diversity number one $=\mathrm{e}^{\mathrm{H}} ; \mathrm{N}_{2}=$ Hill's diversity number two; Hill=Hill's diversity ratio; $\mathrm{I}_{\mathrm{BP}}=$ Berger-Parker's dominance index.

The individual rarefaction curves plotted approached species saturation plateaus with similar slopes for wellmaintained plots, unmaintained plots, non-native species and the overall community. The curve observed in the native species was situated faraway below that of the three other communities, suggesting the lowest species richness at the native species and the highest species richness at the unmaintained plots (Figure 4A).

For a standard sample of 34 specimens, the settlement of unmaintained plots appeared most diverse $\left[\mathrm{E}\left(\mathrm{S}_{\mathrm{n}=34}\right)=11 \pm 0\right.$ species], followed by the overall community $\left[\mathrm{E}\left(\mathrm{S}_{\mathrm{n}=34}\right)=10 \pm 0\right.$ species], by well-maintained plots, by non-native species $\left[\mathrm{E}\left(\mathrm{S}_{\mathrm{n}=34}\right)=8 \pm 0\right.$ species respectively] and lastly by the native species $\left[E\left(S_{n=34}\right)=7 \pm 0\right.$ species] (Figure $4 A$ ).

According to the development stages, rarefaction curves approached species saturation plateaus in St5 plants while it was the contrary in other communities (Figure 4B). For a standard sample of 38 specimens, the settlement in St 4 and St5 plants appeared most diverse $\left[E\left(S_{n=38}\right)=10 \pm 1\right.$ species respectively], followed by $\mathrm{St} 2$ plants $\left[\mathrm{E}\left(\mathrm{S}_{\mathrm{n}=38}\right)=6 \pm 0\right.$ species], by $\mathrm{St} 3$ plants $\left[\mathrm{E}\left(\mathrm{S}_{\mathrm{n}=38}\right)=5 \pm 1\right.$ species] and by St6 plants $\left[\mathrm{E}\left(\mathrm{S}_{\mathrm{n}=38}\right)=3 \pm 0\right.$ species$]$ (Figure 4B). 


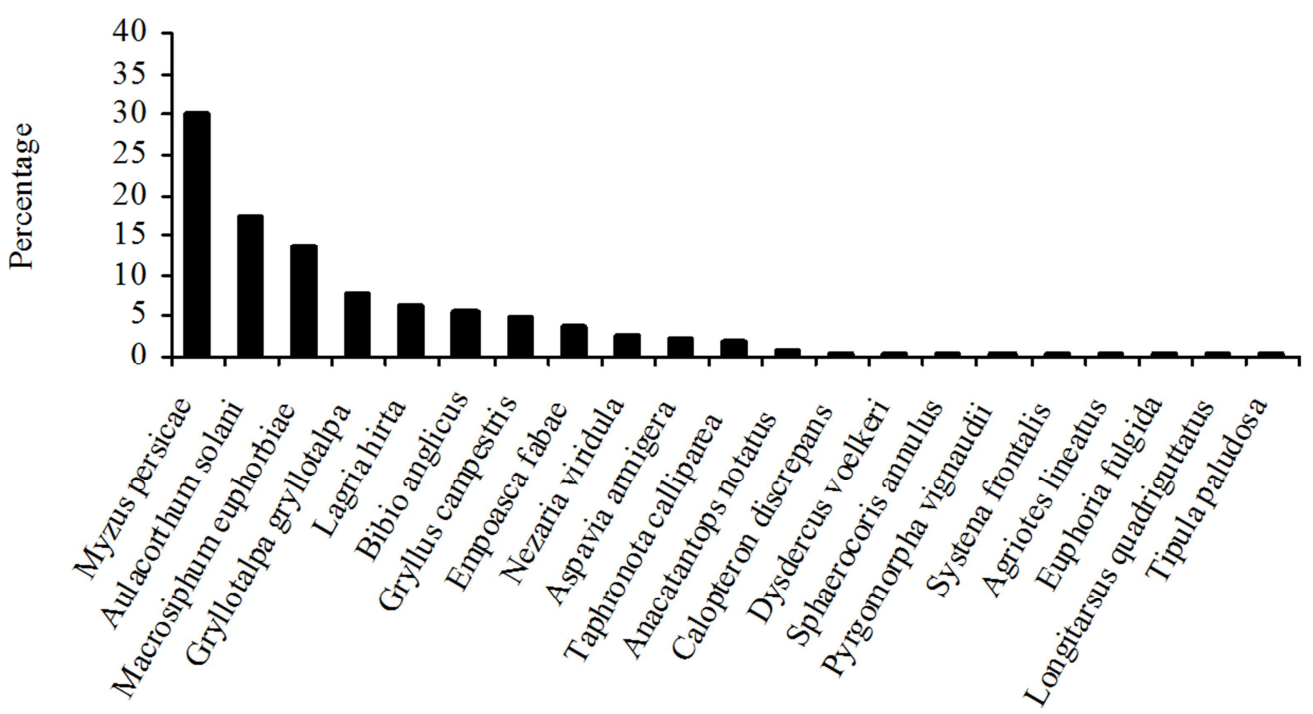

Figure 2. Rank-frequency diagram of the total collected insects showing species in order of numerical dominance.

\subsection{Community Structure}

Based on the species composition, although a few cosmopolitan species were sampled, a high level of dissimilarity was noted between stages 2 and 4 plants communities (Bray-Curtis index: $\mathrm{BC}=0,753$ ) and between well-maintained and unmaintained plots $(\mathrm{BC}=0.697)$. A low level of dissimilarity was noted between the other combinations, the Bray-Curtis dissimilarity index being close to 0 (St2 vs. St3: $\mathrm{BC}=0,231 ; \mathrm{St} 2$ vs. St5: $\mathrm{BC}=0,322 ; \mathrm{St} 2 v s$. $\mathrm{St6}: \mathrm{BC}=0 ; \mathrm{St} 3$ vs. $\mathrm{St} 4: \mathrm{BC}=0,345 ; \mathrm{St} 3$ vs. $\mathrm{St5}: \mathrm{BC}=0,311$; $\mathrm{St} 3$ vs. St6: $\mathrm{BC}=0$; $\mathrm{St} 4$ vs. $\mathrm{St5}: \mathrm{BC}=0,376$; $\mathrm{St} 4$ vs. $\mathrm{St6}: \mathrm{BC}=0$; $\mathrm{St} 5$ vs. St6: $\mathrm{BC}=0$; native species versus non-native species: $\mathrm{BC}=0$ ). The cluster analysis makes possible to recognize at a Jaccard's similarity index equal to 0.3 , three groups: plots of St6 plants formed the first group. The second group consisted of plots of St2, St 4 and St5 plants. The third group consisted of plots of stage 3 plants (Figure 5). Adjustment of the SADs to the five commonly known theoretical models showed that the fit was of satisfactory quality in unmaintained plots ( $\mathrm{r}=$ $0.981, \mathrm{p}=2.5 \times 10^{-11}, \mathrm{r}_{\mathrm{s}}=-0.994, \mathrm{p}=6.6 \times 10^{-15}, 16$ species $)$ and the overall community $\left(r=-0.981, p=6.4 \times 10^{-15}, r_{s}=-0.990\right.$, $\mathrm{p}=1.0 \times 10^{-17}, 21$ species). The fit was of approximate quality in non-native species settlement $\left(\mathrm{r}=-0.958, \mathrm{p}=7.7 \times 10^{-8}, \mathrm{r}_{\mathrm{s}}=-\right.$ $0.978, \mathrm{p}=1.7 \times 10^{-9}, 14$ species). The poor quality fit was noted in well-maintained plots $\left(r=-0.937, p=2.6 \times 10^{-7}, r_{s}=-0.978\right.$, $\mathrm{p}=3.8 \times 10^{-10}, 15$ species) and in the native species assemblage ( $r=-0.943, p=0.002, r_{s}=-0.964, p=0.002$, seven species $)$.

According to the plant development stages, the fit was satisfactory in plots of St 2 plants $\left(\mathrm{r}=-0.971, \mathrm{p}=0.001, \mathrm{r}_{\mathrm{s}}=-\right.$ $0.986, p=0.006,6$ species $)$ and plots of St5 plants $(r=-0.984$, $\mathrm{p}=4.2 \times 10^{-11}, \mathrm{r}_{\mathrm{s}}=-0.989, \mathrm{p}=3.1 \times 10^{-12}, 15$ species $)$. The fit was of poor quality in plots of St 3 plants $\left(r=-0.915, p=0.028, r_{s}=-\right.$ $0.975, \mathrm{p}=0.033,5$ species $)$, plots of St 4 plants $(\mathrm{r}=-0.809$, $\mathrm{p}=1.4 \times 10^{-3}, \mathrm{r}_{\mathrm{s}}=-0.840, \mathrm{p}=6.2 \times 10^{-4}, 12$ species) and plots of St6 plants $\left(r=-0.921, p=0.255, r_{s}=-1 ; p=0.333,3\right.$ species $)$.

On the base of the AIC values (Table 3) and the SAD plotting (Figures 3), the BS model fitted the insect community observed in plots of St 2 plants ( 6 species; $x=6 \pm 2$ individuals). The same result was noted in plots of St6 plants ( 3 species, $x=16 \pm 8$ individuals, $\chi^{2}=6.0, d f=4, p=0.199$ ) and in the native species settlement $(7$ species, $\mathrm{x}=5 \pm 1$ individuals, $\left.\chi^{2}=28.0, \mathrm{df}=24, \mathrm{p}=0.260\right)$. LM fitted the SAD of St4 plants $\left[\mathrm{n}_{1}=14, \mathrm{~m}=0.778\right.$, linear slope $\mathrm{a}=-0.109 \pm 0.025, \mathrm{t}=-4.36$, $\left.\mathrm{p}=0.001, \mathrm{r}^{2}=0.655\right]$. The same trend of LM fitted the community in plots of St5 plants $\left[\mathrm{n}_{1}=58, \mathrm{~m}=0.729\right.$, $\mathrm{a}=-$ $0.137 \pm 0.007, \mathrm{t}=19.84, \mathrm{p}<0.001, \mathrm{r}^{2}=0.968,15$ species $] . \mathrm{LM}$ fitted the community of the unmaintained plots $\left[\mathrm{n}_{1}=58\right.$, $\mathrm{m}=0.758, \mathrm{a}=-0.120 \pm 0.006, \mathrm{t}=-18.82, \mathrm{p}<0.001, \mathrm{r}^{2}=0.962,16$ species, regression ANOVA: $\left.\left.\mathrm{F}_{1 ; 14}=354.075, \mathrm{p}<0.001\right)\right]$. LM also fitted the non-native species settlement $\left[\mathrm{n}_{1}=112\right.$, $\mathrm{m}=0.661, \mathrm{a}=-0.180 \pm 0.016, \mathrm{t}=-11.51, \mathrm{p}<0.001, \mathrm{r}^{2}=0.917,14$ species]. In contrast $\mathrm{Z}$ model fitted the $\mathrm{SAD}$ recorded in $\mathrm{St} 3$ plants (deviance 0.753: $Q=40$ individuals; 5 species: $\gamma=-$ 0.4341) and $\mathrm{ZM}$ model fitted the well-maintained plots community (deviance $=4.591, \mathrm{Q}=141, \mathrm{n}_{1}=54, \mathrm{~S}=15$ species, starting point value $\mathrm{x}_{0}=(1 ; 1)^{\mathrm{T}}$, tolerance of the functional value: $\varepsilon=0.001$, damping factor: $\lambda_{0}=100, \beta=1.182, \gamma=0.574$ ) with a high fractal dimension of the distribution of individuals among species $(1 / \gamma=1.741)$. $\mathrm{ZM}$ model fitted the overall community [deviance $=7.282, \mathrm{Q}=370, \mathrm{n}_{1}=112, \mathrm{~S}=21$ species, $\left.x_{0}=(1 ; 1)^{\mathrm{T}}, \varepsilon=0.001, \lambda_{0}=100, \beta=1.194, \gamma=0.065\right]$ with a high fractal dimension of the distribution of individuals among species $(1 / \gamma=15.408)$.

\subsection{Association and Correlations Between Species}

On the base of 114 sample units from five development stages of the potato plants, overall, the species exhibit a positive association in presence/absence data (Schluter's Variance ratio $\mathrm{VR}=4.85, \mathrm{~W}$ statistic: $24.25, \mathrm{df}=5, \mathrm{p}<0.001)$. Between the seven native species, Elateridae Ag. (Agriotes) lineatus was positively correlated with Gryllidae Gr. (Gryllus) campestris and Gryllotalpidae Gy. gryllotalpa (Kendall's tau correlation: $\tau=1.00, \mathrm{p}=0.014$ respectively). 

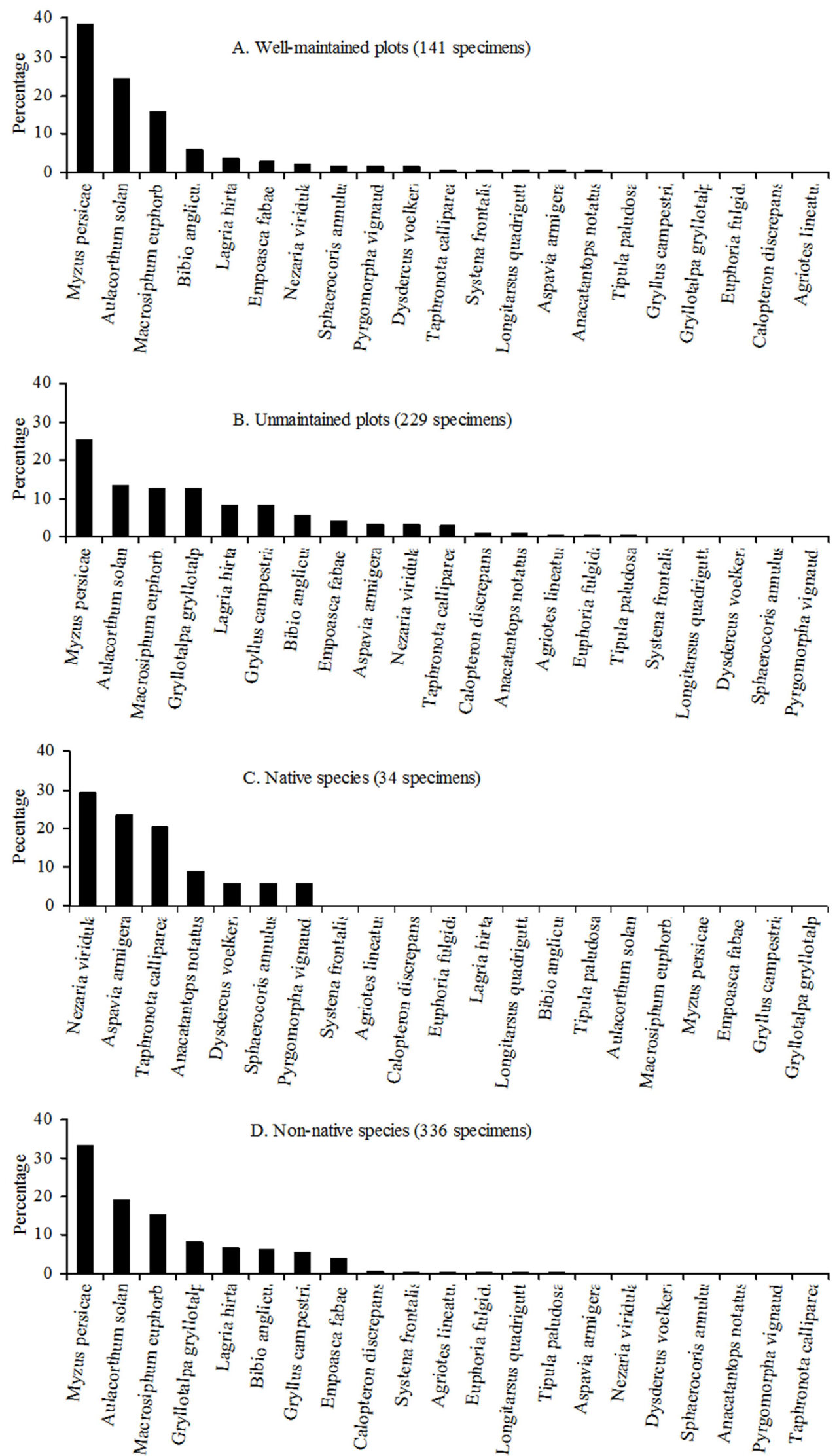

Figure 3. Rank-frequency diagrams of the insect species relative abundances from five development stages of potato plants. For each development stage percentages were calculated on the total number of individuals collected. 
Table 3. Akaike Information Criteria (AIC) values for the adjusted theoretical models.

\begin{tabular}{|c|c|c|c|c|c|c|c|c|c|c|}
\hline \multirow[b]{2}{*}{$\begin{array}{l}\text { SAD theoretical } \\
\text { models }\end{array}$} & \multicolumn{10}{|c|}{ AIC values and the best fitted theoretical model } \\
\hline & $\begin{array}{l}\text { St2 } \\
S=6 \\
n=38\end{array}$ & $\begin{array}{l}S t 3 \\
S=5 \\
n=40\end{array}$ & $\begin{array}{l}S t 4 \\
S=12 \\
n=47\end{array}$ & $\begin{array}{l}\text { St5 } \\
S=15 \\
n=198\end{array}$ & $\begin{array}{l}\text { St6 } \\
S=3 \\
n=47\end{array}$ & $\begin{array}{l}\text { Global } \\
S=21 \\
n=370\end{array}$ & $\begin{array}{l}I \\
S=15 \\
n=141\end{array}$ & $\begin{array}{l}\text { II } \\
S=16 \\
n=229\end{array}$ & $\begin{array}{l}\text { III } \\
S=7 \\
n=34\end{array}$ & $\begin{array}{l}\text { IV } \\
S=14 \\
n=336\end{array}$ \\
\hline Broken-stick & $22.739 *$ & 35.459 & 46.829 & 78.040 & $18.743 *$ & 170.171 & 99.806 & 73.258 & $25.815 *$ & 120.081 \\
\hline Log-linear & 24.684 & 22.077 & $43.632 *$ & $59.604 *$ & 21.087 & 93.312 & 62.460 & $72.057 *$ & 26.190 & $74.637 *$ \\
\hline Log-normal & 27.613 & 22.586 & 47.628 & 68.086 & 22.971 & 96.193 & 63.643 & 78.084 & 28.449 & 88.033 \\
\hline Zipf & 30.323 & $19.941 *$ & 47.024 & 83.438 & 26.324 & 124.060 & 65.253 & 98.760 & 29.026 & 119.449 \\
\hline Zipf-Mandelbroot & 28.528 & 21.941 & 45.798 & 63.450 & 24.972 & $91.142 *$ & $58.244 *$ & 75.978 & 29.870 & 78.627 \\
\hline
\end{tabular}

SAD: Species Abundance Distribution, St2 to St6, I to III see table 1, III: Native species, IV: Non-native species, S: species richness, n=sample size, * the best fitted theoretical model.
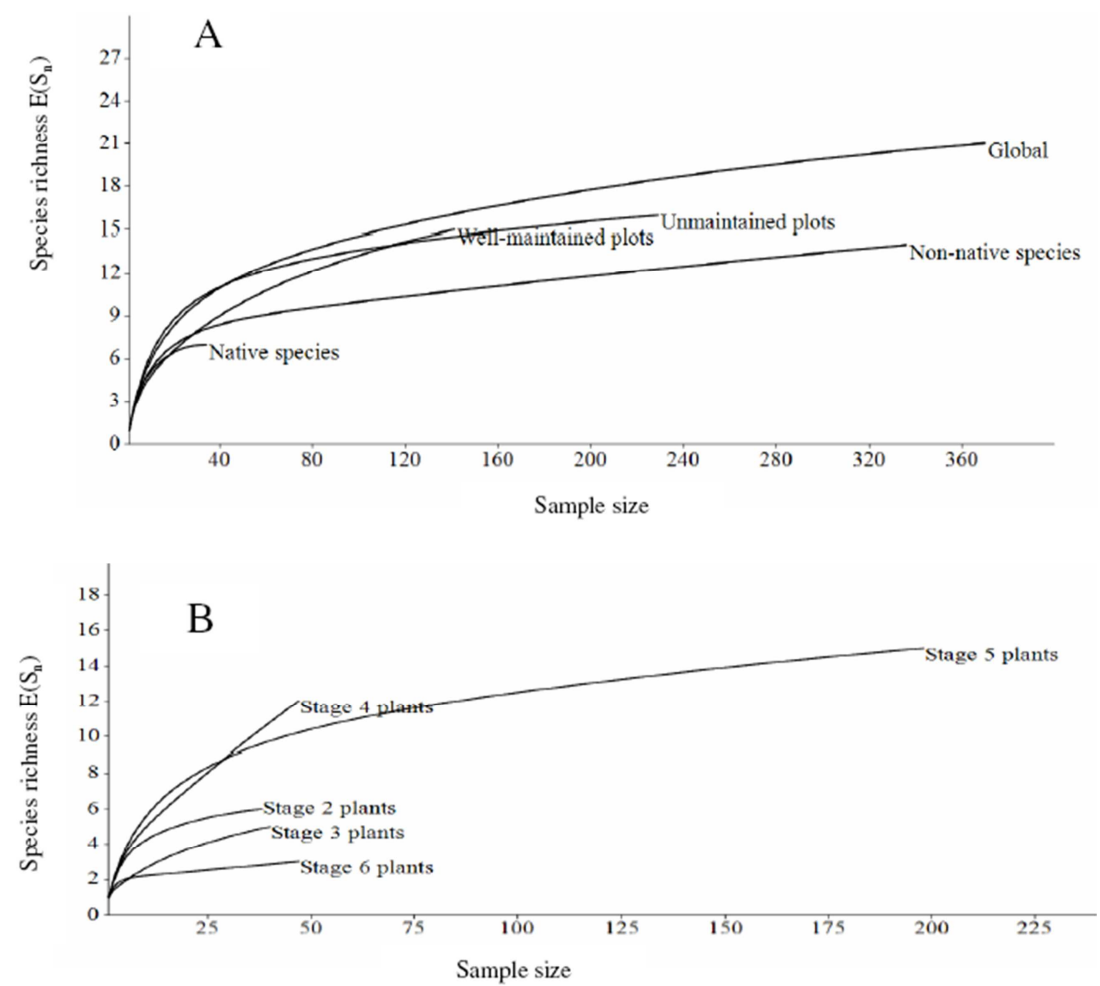

Figure 4. Species rarefaction curves among the species richness from five development stages of potato plants. A: Species rarefaction per origin of insects and the cleanliness of plots; $B$ : Species rarefaction per plant development stages.

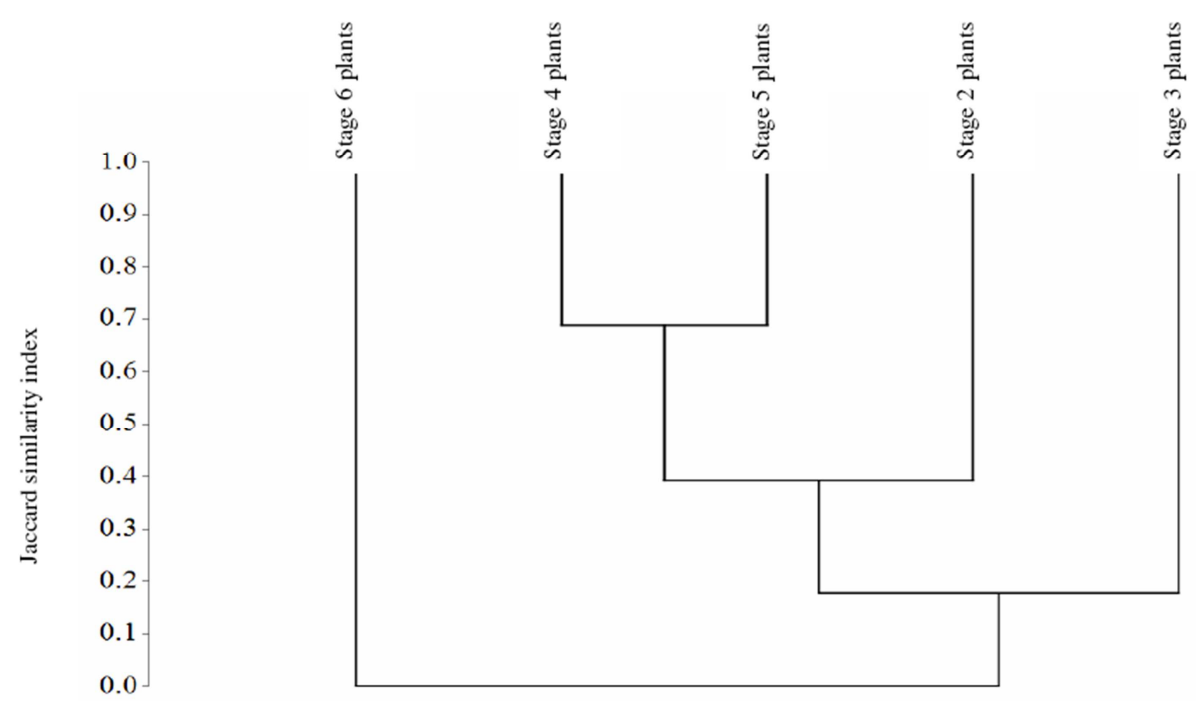

Figure 5. Hierarchical Cluster Analysis based on Jaccard's index using the "Unweighted Pair Group Method with Arithmetic mean" (UPGMA) algorithm and showing similarity in insect communities among five development stages of potato plants (Cophenetic correlation: 0.996). 
The Pentatomidae As. armigera was positively correlated with Acrididae An. notatus (Kendall's correlation: $\tau=1.00$, $\mathrm{p}=0.014)$, with Pentatomidae $N$. viridula $(\tau=0.88, \mathrm{p}=0.031)$, with two Pyrgomorphidae $[P$. vignaudii and Ta. (Taphronota) calliparea; $\tau=0.93, \quad \mathrm{p}=0.024$ and $\tau=1.00, \quad \mathrm{p}=0.014$ respectively] and with Scutelleridae Sp. annulus $(\tau=0.93$, $\mathrm{p}=0.023) . N$. viridula was positively correlated with $T a$. (Taphronota) calliparea $(\tau=0.88, \mathrm{p}=0.031) . S p$. annulus was positively correlated with $\mathrm{Ta}$. (Taphronota) calliparea $(\tau=0.93, \mathrm{p}=0.024)$. And $P$. vignaudii was positively correlated with Ta. (Taphronota) calliparea $(\tau=0.93, p=0.023)$. Amongst the species of the Neartic native range, positive correlations were recorded between Lycidae $C$. discrepans, Scarabaeidae Eu. fulgida fulgida and Tipulidae Ti. paludosa $(\tau=1.00$, $\mathrm{p}=0.014$ respectively). And Aphididae Ma. euphorbiae was positively correlated with Cicadellidae Em. fabae $(\tau=1.00$; $\mathrm{p}=0.014$ ). Amongst the species of Holartic native range, Aphididae $A u$. solani was positively correlated with three afrotropical native species (Acrididae An. notatus, Pentatomidae [As. armigera and Pyrgomorphidae Ta. (Taphronota) calliparea; $\tau=0.88, \mathrm{p}=0.031$ respectively]). Bibionidae $B$. anglicus was positively correlated with two species of Neartic origin Aphididae Ma. euphorbiae and Cicadellidae Em. fabae ( $\tau=1.00 ;$ p $=0.014$ respectively).

The Gryllidae Gr. (Gryllus) campestris was positively correlated with Gryllotalpidae Gy. gryllotalpa $(\tau=1.00$, $\mathrm{p}=0.014)$. Tenebrionidae Lo. quadriguttatus was positively correlated with the Pyrrhocoridae afrotropical native species D. voelkeri $(\tau=1.00, \mathrm{p}=0.014)$. Apart from these significant correlations, the other correlations were not significant and the tetrachoric correlations determined on the presence/absence data showed in all cases no significant attraction or repulsion. Thus, at different development stages of the plants, after treatments of the crop plots with chemical pesticides, some species of Holartic origin were positively correlated with a few afrotropical native species and a few Neartic species.

\subsection{Damages on the Aerial Organs of Plants}

Despite chemical treatment using insecticides, destroyed aerial plant organs were recorded $(1.8 \%$ of perforated stems, $6.6 \%$ of nibbled leaves, $3.4 \%$ of nibbled flowers and $24.8 \%$ of drilled tubers; Table 4).

Table 4. Percentage of healthy and damaged aerial organs of potato plants.

\begin{tabular}{|c|c|c|c|c|c|c|c|c|}
\hline \multicolumn{5}{|c|}{ A. Stems } & \multicolumn{4}{|l|}{ B. Leaves } \\
\hline Plots & Healthy (\%) & Damaged (\%) & Total (\%) & p-value & Healty (\%) & Damaged (\%) & Total (\%) & p-value \\
\hline St2 & $534(18.6)$ & - & $534(18.6)$ & $2.6 \times 10^{-320} *$ & $7,591(10.2)$ & $351(0.5)$ & $7,942(10.7)$ & $\mathrm{p}<0.001 *$ \\
\hline St3 & $844(29.4)$ & $17(0.6)$ & $861(30.0)$ & $<0.001 *$ & $15,766(21.2)$ & $741(1.0)$ & $16,507(22.2)$ & $\mathrm{p}<0.001 *$ \\
\hline St4 & $593(20.7)$ & $16(0.6)$ & 609 (21.3) & $3.8 \times 10^{-303} *$ & $16,407(22.1)$ & 848 (1.1) & $17,255(23.2)$ & $\mathrm{p}<0.001 *$ \\
\hline St5 & 847 (29.5) & $17(0.6)$ & $864(30.1)$ & $<0.001 *$ & $29,719(40.0)$ & $2,954(4.0)$ & $32,673(43.9)$ & $\mathrm{p}<0.001 *$ \\
\hline I & $1,971(68.7)$ & $33(1.2)$ & $2,004(69.9)$ & $<0.001 *$ & $39,764(53.5)$ & $1,940(2.6)$ & $41,704(56.1)$ & $\mathrm{p}<0.001 *$ \\
\hline II & 847 (29.5) & $17(0.6)$ & $864(30.1)$ & $<0.001 *$ & $29,719(40.0)$ & $2,954(4.0)$ & $32,673(43.9)$ & $\mathrm{p}<0.001 *$ \\
\hline III & $2,818(98.2)$ & $50(1.8)$ & $2,868(100.0)$ & $<0.001 *$ & $69,483(93.4)$ & $4,894(6.6)$ & $74,377(100.0)$ & $\mathrm{p}<0.001 *$ \\
\hline FFHT & \multicolumn{4}{|c|}{$\chi^{2}=18,31 ; \mathrm{df}=3 ; \mathrm{p}=3.3 \times 10^{-7} *$} & \multicolumn{4}{|c|}{$\chi^{2}=577.53 ; \mathrm{df}=3 ; \mathrm{p}<0.001 *$} \\
\hline I vs. II & $\mathrm{p}<0.001 *$ & $\mathrm{p}=0.002 *$ & $<0.001 *$ & & $\mathrm{p}<0.001 *$ & $\mathrm{p}<0.001 *$ & $\mathrm{p}<0.001 *$ & \\
\hline Global & \multicolumn{4}{|c|}{$\chi^{2}=0.429 ; \mathrm{df}=1 ; \mathrm{p}=0.537 \mathrm{~ns}$} & \multicolumn{4}{|c|}{$\chi^{2}=569.60 ; \mathrm{df}=1 ; \mathrm{p}=7.0 \times 10^{-126} *$} \\
\hline Plan organ & \multicolumn{4}{|c|}{ C. Flowers } & \multicolumn{4}{|c|}{ D. Tubers } \\
\hline Plots & Healty $(\%)$ & Damaged (\%) & Total $(\%)$ & p-value & Healty $(\%)$ & Damaged (\%) & Total (\%) & $\mathrm{p}$-value \\
\hline St3 & $2,338(35.8)$ & $108(1.7)$ & $2,446(37.4)$ & $<0.001 *$ & - & - & - & - \\
\hline St4 & $3,970(60.8)$ & $116(1.8)$ & $4,086(62.6)$ & $<0.001 *$ & - & - & - & - \\
\hline St6 & - & - & - & & $451(75.2)$ & $149(24.8)$ & $600(100.0)$ & $\mathrm{p}<0.001 *$ \\
\hline Total & $6,308(96.6)$ & $224(3.4)$ & $6,532(100.0)$ & $<0.001 *$ & $451(75.2)$ & $149(24.8)$ & $600(100.0)$ & $\mathrm{p}<0.001 *$ \\
\hline Statistic & \multicolumn{8}{|c|}{$\chi^{2}=2.93 ; \mathrm{df}=1 ; \mathrm{p}=0.104 \mathrm{~ns}$} \\
\hline I & $6,308(96.6)$ & $224(3.4)$ & $6,532(100.0)$ & $<0.001 *$ & - & - & - & \\
\hline II & - & - & - & & $451(75.2)$ & $149(24.8)$ & $600(100.0)$ & $\mathrm{p}<0.001 *$ \\
\hline III & $6,308(96.6)$ & $224(3.4)$ & $6,532(100.0)$ & $<0.001 *$ & $451(75.2)$ & $149(24.8)$ & $600(100.0)$ & $\mathrm{p}<0.001 *$ \\
\hline \multicolumn{9}{|c|}{ Fisher exact test } \\
\hline $\mathrm{St} 3$ vs. St4 & $\mathrm{p}<0.001 *$ & $\mathrm{p}=0.637 \mathrm{~ns}$ & $\mathrm{p}<0.001 *$ & & - & - & - & \\
\hline \multicolumn{9}{|c|}{ Pairwise comparisons of damaged plant organs occurrences: $\alpha^{\prime}$ (p-value) } \\
\hline Comparison & \multicolumn{2}{|c|}{ Stems } & \multicolumn{2}{|c|}{ Leaves } & & & & \\
\hline St 2 vs. St 3 & \multicolumn{2}{|l|}{-} & \multicolumn{2}{|c|}{$0.017\left(7.0 \times 10^{-33} *\right)$} & & & & \\
\hline St2 vs. St4 & \multicolumn{2}{|l|}{-} & \multicolumn{2}{|c|}{$0.013\left(2.9 \times 10^{-48} *\right)$} & & & & \\
\hline St2 vs. St5 & \multicolumn{2}{|c|}{-} & \multicolumn{2}{|c|}{$0.008(<0.001 *)$} & & & & \\
\hline $\mathrm{St} 3$ vs. St4 & \multicolumn{2}{|c|}{$0.025(1.000 \mathrm{~ns})$} & \multicolumn{2}{|c|}{$0.025(0.007 *)$} & & & & \\
\hline $\mathrm{St} 3$ vs. St5 & \multicolumn{2}{|c|}{$0.017(1.000 \mathrm{~ns})$} & \multicolumn{2}{|c|}{$0.050\left(1.6 \times 10^{-317 *}\right)$} & & & & \\
\hline St 4 vs. St5 & \multicolumn{2}{|c|}{$0.050(1.000 \mathrm{~ns})$} & \multicolumn{2}{|c|}{$0.010\left(605 \times 10^{-277} *\right.$} & & & & \\
\hline
\end{tabular}

FFHT, I to III, St2 to St6, -, $\alpha$ ' and * see table 1.

Attacks of plants by phytophagous insects is probably due to insect from nearby untreated fallows, or to insects that have escaped the chemical pesticides, because hidden in microhabitats inaccessible by the chemicals (case of insects with hypogeal larvae developing in the soil), or the cleaning of the treated plants by rainwater. Tubers with black scars 
suggested the point of drilling and thus were damaged by borer larvae. The borehole was scarred when the boring larva was still lodged in the tuber, or opened when the larvae has left the tuber. Infested tubers were unfit for consumption and marketing and therefore constituted a loss for the gardener. A total of 84,377 specimens of plant organs $(74.7 \%$ flowers, $0.7 \%$ tubers, $88.1 \%$ leaves and $3.4 \%$ stems) were surveyed in 16 plots. Stems and tubers were drilled $(1.8 \%$ and $24.8 \%$ respectively) (Table 4A and 4D). Flowers and leaves were nibbled or perforated $(3.4 \%$ and $6.6 \%$ respectively) (Table $4 \mathrm{~B}$ and $4 \mathrm{C})$. The number of perforations on stems varied from one to two $(1.06 \pm 0.03)$. The low percentage of destruction was noted on stems while the high percentage was noted on tubers. Whatever the plant development stage, percentage of damaged organs was lower than that of healthy organs. Damages recorded on leaves and flowers were quantitatively intermediate between the 2 extremes (Table 4). The health of the plant and its photosynthetic potential remains affected. To the influence of insects, is very often added limiting effect of soil water content, soil fertility and effect of several pathogens (viruses, microscopic fungi and bacteria). The damage rate was low in unmaintained plots than in well-maintained plots (Table 4).

\section{Discussion}

\subsection{Species Richness, Abundance and Dominance}

The present study is the first step in evaluating impact of native and non-native species on the insect assemblage of the potato plants cultivated in the rural zone of Balessing (WestCameroon) especially when chemical treatments are stopped. The cultivated potato plots showed two weeks after stopping the pesticide treatment, a relatively low abundance and number of insect species with the high representation of nonnative pest species. Similar results are reported in grounddwelling ant communities in anthropized environments [8790]. According to the reports of these authors, the strongly anthropized sites are clearly less diverse than the sites undergoing regeneration process. Our studies revealed the presence of 23 insect species belonging to five orders and 18 families responsible of the damage on the potato plants aerial organs. Hemiptera represented more than $70.5 \%$ of the pest insects sampled $(33.0 \%$ in well-maintained plots and $37.6 \%$ in unmaintained plots) while Coleoptera and Orthoptera represented respectively $7.8 \%$ and $15.7 \%$ of sampled insects, Diptera represented only $5.9 \%$ of the collected insects. Two Lepidoptera families (Crambidae and Noctuidae) were sampled from damaged stems and tubers. The recent report by Dzokou et al. [71] shows that these orders and families damage Piper nigrum L. in Penja-Cameroon. The peculiarity of our results is that they are active on plants two weeks after the insecticide treatments, suggesting either the recolonization of the fields from the neighbouring untreated fallows, or the cleaning of aerial plant organs by rainwater, or an appearance of individuals resistant to insecticides or that the larvae of boring insects were already installed in the tissues of the plant when the chemical insecticide was applied. Resistance would have been developed as a consequence of anarchic and uncontrolled use of pesticides by undereducated farmers of the locality [8, 21-24]. The low diversity of the insect pests is associated with low abundance in native species (seven species i.e. $33.3 \%$ of the total species richness and $9.0 \%$ of the total insect abundance), resulting in the weak exploitation of resources. The exploitation of both food and nest sites was mostly achieved by non-native species (14 non native species i.e. $66.7 \%$ of the species richness and $91.0 \%$ of the total abundance). The high abundance level of the invasive non-native species in their introduced range is well known in ant communities [90]. The low insect species diversity recorded reflects the negative effect of the chemical treatments or the presence of both five native pest species [As. armigera (Hemiptera: Pentatomidae), Dy. voelkeri (Hemiptera: Pyrrhocoridae), Ne. viridula (Hemiptera: Pentatomidae), Py. vignaudii Orthoptera: Pyrgomorphidae) and Sp. annulus (Hemiptera: Scutelleridae) $]$ and the eight non-native pest species $[\mathrm{Ag}$. (Agriotes) lineatus (Coleoptera: Elateridae), Au. solani (Hemiptera: Aphididae), Em. (Empoasca) fabae (Hemiptera: Cicadellidae), Ma. euphorbiae (Hemiptera: Aphididae), My. persicae (Hemiptera: Aphididae), Sy. frontalis (Coleoptera: Chrysomelidae), Ti. paludosa (Diptera: Tipulidae) and $G y$. gryllotalpa (Orthoptera: Gryllotalpidae)]. The recorded native species are frequently reported in West Africa as field pests on several plant species such as cotton Gossypium sp. (Malvaceae), soybean Glycine max (L.) Merr., 1917 (Fabaceae), chickpea Vigna mungo (L.) Hepper (Fabaceae), Sorghum sp. (Poaceae), cowpea Vigna unguiculata (L.) Walp., 1843 (Fabaceae) and rice Oryza sativa L., 1753 (Poaceae) [12, 58, 61, 63, 91, 92]. Non-native species damage cultivated plants not only in their native range but also in areas of introduction. This is the case of the European native wireworms (Agriotes spp.) including Ag. lineatus (L.), $A g$. obscurus (L.) and $A g$. sputator (L.) on potato plants in Canada, Sweden, Poland, United Kingdom [41, 42, 93]. This is also the case of the aphids Au. solani, Ma. euphorbiae and My. persicae which are serious pests in greenhouses of North America, Europe and India where they are vectors of the plant's viruses [50, 53, 54, 55]. These aphids are highly polyphagous and have developed resistance to several insecticides in several countries. Transfer of aphids from neighbouring fallows to cultivated potato plots may be the work of ground-dwelling and arboreal-foraging ant species, as is the case after stopping applications of insecticides in citrus orchards in Cameroon [94]. Potato leafhopper Em. (Empoasca) fabae is a pest sap-feeding insect that attacks potato plants in the region of Washington and Oregon Columbia Basin and Yakima Valley [95] and it attacks a variety of other plants including cotton Gossypium sp. (Malvaceae), alfalfa Medicago sativa L., 1753 (Fabaceae) and soybean G. $\max$ (Fabaceae) in South Sulawesi (Indonesia) [96]. The red-headed flea beetle Systena frontalis is increasingly being identified as an emerging pest of concern in cranberries Vaccinium macrocarpon Aiton 
(Ericales: Ericaceae) and in ornamental plant nurseries in the United States where adults emerge sporadically from the cryptic larvae over the summer and feed on both fruit and foliage, and preferentially on new plant growth [35, 39]. In Canada and North America, injuring grasses, extensive damage and loss of yields in beets fields, canola (colza) fields, cereal fields, corn Zea mays L. (Poaceae), strawberries Fragaria ananassa (Weston) Duchesne ex Rozier, 1785 (Rosaceae) soybean fields and other crops, have been attributed to the most injurious euopean crane-fly $T i$. paludosa [97]. The European mole cricket Gy. gryllotalpa is one of the most important pests in turf and field crops of Iran and its damage in some areas is economically significant [66]. In addition we recorded in the studied plots the presence of the noctuid pest species Helicoverpa armigera and Lecinodes orbonalis which are polyphagous pests causing heavy yield loss in agricultural, ornamental and horticultural crops $[98,99]$. Then on the basis of the reports of the various authors concerning the harmful activity of exotic species in the localities of introduction, they would carry out a similar activity in the plantations of potatoes cultivated in the locality of Balessing. Our results showed a low occurrence level of the native pest species, in the presence of the non-native species generally considered as among the most ecologically destructive in cultivated areas where they have been introduced. The low representation of native species could be the result either of the regulation of their populations by local natural enemies, or of a significant negative force of introduced species, as is the case reported in ant communities [41, 42, 50, 54, 90]. World-wide, synthetic pesticides are commonly used for pest control. But in Australia, India, United States of America and Thailand, inappropriate use of synthetic pesticides against $H$. armigera, Le. orbonalis and other pest insects has resulted in many unwanted effects such as environmental pollution, non-target effect and human health hazards and the development of resistance to almost all classes of insecticides including pyrethroids (cypermethrin, cyhalothrin, deltamethrin and fenvalerate), cabamates (carbaryl), organochlorates (endosulfan), organophosphates (chlorpyriphos and profenofos) [53, 55, 94-96, 100]. A similar situation would arise in Balessing locality if the phytosanitary authorities do not take adequate measures to educate gardeners and thus protect the environment and populations. Chrysomelidae $(0.3 \%)$, Elateridae $(0.3 \%)$, Tipulidae $(0.3 \%)$, Aphididae (61.1\%), Cicadellidae (3.5\%), Pentatomidae (4.9\%), Pyrrhocoridae $(0.5 \%)$, Scutelleridae $(0.5 \%)$, Orthoptera Gryllotalpidae (7.6\%) and Pyrgomorphidae (0.5\%) cumulatively represented $79.5 \%$ of the total insect collection. Our results are contrary to those reported in potato plants fields in Indonesia [58], in eggplants fields in Bangladesh [15] and Ivory Coast [10], where Homoptera Aphididae were most abundant. The low representation of Coleoptera $(7.9 \%)$, Diptera $(6.0 \%)$ and Orthoptera $(15.7 \%)$ could be explained not only by the action of pesticides but also by the fact that the dominance by an insect species in a potato field may depend on the geographical area, the season of the year, the farming and the cropping systems that significantly affect the population of pests as is the case in Indonesia [35, 39]. In the locality of Balessing (Cameroon), the insect's richness in potato fields, recorded two weeks after stopping synthetic pesticide applications, is quite lower than results reported in olericulture crops in Pakistan were 389 specimens, 10 orders, 33 families and 59 species were recorded in spinach fields Spinacia oleracea L. (Amaranthaceae), 327 specimens, nine orders, 30 families and 55 species where recorded in fenugreek fields Trigonella foenum-graecum (Fabaceae), 373 specimens related to 11 orders, 34 families and 61 species were recorded in turnip fields Brassica rapa var. rapa L. (Brassicaceae) [49, 101]. Our results are however superior to those recorded in Ghana in tomato crops where 14 insect species belonging to 14 families were recorded [92]. These insects pose a threat to potato plants as well as other vegetable crops. In fact, in Sudan, 28 pest species that damage untreated eggplant fields were divided into 18 phytophagous species, seven species that destroy flowers and fruits; three stem borer species. Similarly in Bangladesh, the 20 insect species that damage eggplant plants are divided into 15 phytophagous species, three pest species of flowers and fruits and two boring species of stems and roots [15]. Sapfeeding species Au. solani (17.3\%), Ma. euphorbiae (13.5\%) and My. persicae (30.3\%), were highly abundant and the most destructive on flowers, leaves and stems. This result is contrary to that of Srinivasan [100] who reported the dominance of Lepidoptera in plots of eggplant crops in Taiwan. The presence of $H$. armigera (Lepidoptera: Noctuidae) and Le. orbonalis (Lepidoptera: Crambidae) in the field suggests a negative impact on the stems and leaves of plants, as is the case in eggplant plantations in Taiwan [102]. Indeed, these insects are oligophagous and attack leaves and fruits of several plant species including Solanaceae plants [97]. The availability of these plant species in neighbouring fallows would represent a microhabitat favourable to the propagation of the pest insects.

Based on the total of 5,317 damaged plant organs, the damage caused by pest species was greater on leaves $(92.0 \%$ of attack) more precisely on stage 5 development plants (stages 2 plants: $6.6 \%$; stage 3 plants: $13.9 \%$; stage 4 plants: $15.9 \%$; stage 5 plants: $55.6 \%$ ) while low rates of attack were recorded on other plant organs (stems: $0.9 \%$; flowers: $2.8 \%$; and tubers: $4.2 \%$ ). This can be explained by the fact that at the flowering development stage 5, leaves and flowers emits volatile compounds that attract insects including phytophagous and flower nectar suckers as is the case in Ivory-Coast in eggplant plantations where fruiting stage plants do attrack insects than other plant organs [12]. The differences observed could be explained by the study periods with the high frequency of heavy rains which wash the insecticides; the misuse of pesticides by poorly educated farmers, the attacks in the field by insects varying considerably according to the phenological stage of the plant. The interpretation of the model is based on a hypothetical form of sharing of biotope resources between the species present. In practical, this model is suitable for the analysis of 
communities in which interspecies relationships are elementary, competition being essentially limited to the level of a resource, such as physical space. Considering quantity and frequency use of pesticides, it is obvious that pest insects are from neighbouring fallows where wild species of host plants may be present.

\subsection{Community Structure Model}

On the base of the AIC values, insects from plots of stage 2 and 6 plants and the native species belonged to the same BS model which describes the nonlinear relationship between abundance and ranks of the species and characterizes a stand in which the different species share an important resource of the environment. Insects from plots of stages 4 and 5 plants and from unmaintained plots belonged to the same GM nomocenose, the Motomura's environmental constant reaching in each case a high value (closed to one). GM (preemption of the niche) describes a linear relationship between logarithm of species abundances and ranks. Contrary to the LM (Preston) which describes the relationship between the logarithm of the abundance and the probit of the ranks of the species and which reflects a community where the majority of species shows moderate abundances, the GM corresponds to a community in which a reduced number species is largely dominant. GM model is reported fitting SADs of several insect communities, for example Carabidae and Heteroptera inhabiting road verges and meadow-pasture pairs in managed grasslands [66, 98, 103-106], sand flies communities in the Mayombe region of Congo [107] and grasshopper community in different types of vegetation in the Littoral of Cameroon [64]. This model therefore seems to characterize the stands of open forests and disturbed environments, where there is strong competition between pioneer species for the exploitation of available resources. The insect community from plots of stage 3 plants fitted the $\mathrm{Z}$ model while the overall global community and the well-maintained plots exhibited a ZM model. ZL was initially applied to socioeconomic and linguistic systems, but it is now used to represent SADs in insect communities [105]. $Z$ model based on $\mathrm{ZL}$ assumes that the frequency of all species is inversely proportional to its rank. ZM model describes an order of appearance of species according to their decreasing requirement to environmental conditions. Then a ubiquitous species will appear very early and be abundant, while a specialized species will appear later, when the first species have modified the environment, and in small numbers. ZM model is frequently fitted by communities in natural environments, suggesting evolved ecosystems where the multi-species networked structure corresponds to an optimal structure for the circulation of information carried out on spatio-temporal scales [108]. Human activities in general resulting in urbanization, growing cities, extensive deforestation and the extension of cultivated areas have been reported to modify land cover, to reduce the area of natural habitats, to affect ecosystem functioning and to contribute to the loss of biodiversity [109]. Our results show that in the potato fields in Balessing, the overall insect community and the well-maintained plots community had a complex network of information quite close to that of evolved environments. Therefore, potato plots present in Balessing a fairly significant regeneration force compared to highly disturbed urban environments.

\section{Conclusion}

In Balessing potato fields are invaded by alien pest insects. Their negative impact on cultivated vegetable crops is known in several countries. In Balessing locality, all the conditions combine to soar. Due to the numerical and behavioural dominance of alien insects, a significant number of resources are potentially exploitable. These species could acquire other resources, as most as they are exploited by native species. In due course, once the invaders would completely monopolize available resources and saturate the area, it would not allow native species the niche opportunities to re-establish themselves. The consequences of loosing these native species, which may well interact with the diverse and endemic flora, will be of extreme concern. The high occurrence of pests $(66.7 \%$ made up of $38.1 \%$ and $28.6 \%$ for native and non-native species respectively) necessitates the reaction of the national phytosanitary control service to reduce economic losses.

\section{Acknowledgements}

The authors acknowledge the Cameroonian Ministry of Higher Education for providing funds through the research support program for carrying out field works. They are also grateful to the members of the Biological Control Unit of the Laboratory of Biology and Physiology of Animal Organisms, Faculty of Sciences, University of Douala, for the technical support during identification of insect specimens. The authors thank the farmers of Balessing for their hospitality and access to their plots.

\section{References}

[1] Vreugdenhil, D., Bradshaw, J., Gebhardt, C., Govers, F., MacKerron, D. K. L., Taylor, M. A., \& Ross, H. (2007). Potato biology and biotechnology (advances and perspectives). Elsevier, The Boulevard, Langford Lane, Kidlington, Oxford, Amsterdam, the Netherlands, Pp. 823.

[2] Eke-Ejiofor, J., \& Owuno, F. (2014). The Functional Properties of Starches, Physico-Chemical and Sensory Properties of Salad Cream from Cassava and Potatoes, Int. J. Food Sci., 3 (6): 567-571.

[3] Mahamud, M. A., Chowdhury, M. A. H., Rahim, M. A., \& Mohiuddin, K. M. (2015). Mineral nutrient contents of some potato accessions of USA and Bangladesh. J. Bangladesh Agril. Univ., 13 (2): 207-2014.

[4] Muthoni, J., \& Kabira, J. N. (2015). Potato Production in the Hot Tropical Areas of Africa: Progress Made in Breeding for Heat Tolerance. J. Agric. Sci., 7 (9): 220-227. 
[5] Chauvin, N. D., Mulangu, F., \& Porto, G. (2012). Food production and consumption trends in sub-Saharan Africa: Prospects for the transformation of the agricultural sector. UNDP Regional Bureau for Africa, New York, USA, Pp. 76.

[6] Manishimwe, R., Niyitanga, F., Nsabimana, S., Kabayiza, A., \& Mutimawurugo, M-C. (2019). Socio-economic and Institutional Factors Influencing the Potato (Solanum tuberosum L.) Production at Smallholder Farmers Level in the Gicumbi District in Rwanda. Tropicultura, 37 (2): 2295-8010.

[7] Basha, K., Ewang, P. N., \& Ndemo, Okoyo, E. (2017). Factors Affecting productivity of Smallholder potato Growers in Bore District, Guji Zone, Oromia Regional State, Ethiopia. Developing Country Studies, 7 (9): 18-26.

[8] Ngameni, Tchamadeu, N., Kenko, Nkontcheu, D. B., \& Djomo, Nana, E. 2017. Evaluation des facteurs de risques environnementaux liés à la mauvaise utilisation des pesticides par les maraîchers au Cameroun: le cas de Balessing à l'Ouest Cameroun. Afr. Sci., 13 (1): 91-100.

[9] Mengui, K. C., Oh, S., \& Lee, S. H. (2019). The Technical Efficiency of Smallholder Irish Potato Producers in Santa Subdivision, Cameroon. Agriculture, 9 (12): 259.

[10] Obodji, A., Aboua, L. R. N., Tano, D. K. C., \& Seri-Kouassi, B. P. (2016). Inventory of entomofaune associated with African eggplant (Solanum aethiopicum L.) according to the phonological stages assessment of damages caused by insect pests. J. Adv. Stud. Agric. Biol. Environ. Sci., 3 (2): $2455-$ 0221 .

[11] Cook, D., Herbert, A., Akin, D. S., \& Reed J. (2011). Biology, Crop Injury, and Management of Thrips (Thysanoptera: Thripidae) Infesting Cotton Seedlings in the United States. J. Integr. Pest Manag., 2 (2): 1-9.

[12] Johnson, F., Gbon, G. A., Boga, J. P., \& N'Goran, A. (2019). Incidence des insectes et des nématodes sur la production de l'aubergine Solanum aethiopicum Linné, 1756. Variété Djamba F1 dans la zone périurbaine d'Abidjan, Côte d'Ivoire. Int. J. Multidiscip., 6: 6-11.

[13] Babar, H. C., Asif, H. C., Abdul, G. L., Aslam, B., Imtaiz, A. N., Ammara, R., Fida, H. M., Mehroz, K., Farukh, A., \& Zehua, Z. (2019). Insect Biodiversity in Brinjal AgroEcosystem. Pak. J. Sci. Ind. Res. A: Phys. Sci., 62B (3): 199205.

[14] Deffo, V., \& Demo P. (2003). Adoption of two new potato varieties in Cameroon: Progress and constraints. Am. J. Potato Res., 80 (4): 263-269.

[15] Latif, M. A., Rahman, M. M., Islam, M. R., \& Nuruddin, M. M. (2009). Survey of Arthropod Biodiversity in the Brinjal Field. J. Entomol., 6 (1): 28-34.

[16] Abossolo, S. A., Batha, R. A. S., \& Djeugang, A. B. (2015). Identification des risques pluviométriques sur la culture du maïs dans l'arrondissement de Penka-Michel, dans les hautes terres de l'Ouest du Cameroun. Afr. Sci., 11 (2): 136-146.

[17] Kottek, M., Grieser, J., Beck, C., Rudolf, B., \& Rubel F. (2006). World Map of the Köppen-Geiger climate classification updated. Meteorol. Z., 15 (3): 259-263.

[18] Tsalefac, M., Ngoufo, R., Nkwambi, W., Djoumessi, Tatsangue, E., \& Lengue Fobissie, B. (2003). Fréquences et quantités des précipitations journalières sur le territoire camerounais. Publ. Assoc. Intern. Climatol., 15: 359-367.
[19] JESBAD (2013). Connaitre Balessing. Jeunesse Estudiantine et Scolaire Balessing de Douala (Cameroun), Pp. 69.

[20] MINADER (2019). Liste des pesticides homologués au Cameroun au 18 Avril 2019. Liste réservée au grand public. Ministère de l'Agriculture et de Développement Rural. Commission Nationale d'Homologation des Produits Phytosanitaires et de Certification des Appareils de Traitement (CNHPPCZT), Yaoundé, Cameroun, Pp. 212.

[21] Sonchieu, J., Ngassoum, M. B., Nantia, Akono, E., \& Laxman, P. S. (2018). Pesticide Applications on Some Vegetables Cultivated and Health Implications in Santa, North WestCameroon. SSRG Int. J. Agric. Env., 4 (2): 39-46.

[22] Konje, C. N., Abdulai, A. N., Tange Achiri, D., Nsobinenyui, D., Tarla, D. N., \& Awah Tita, M. (2019). Identification and Management of Pests and Diseases of Garden Crops in Santa, Cameroon. J. Agric. Ecol., 18 (2): 1-9.

[23] Ntonifor, N. N., Nsobinenyui, D. N. S., Fokam, E. B., \& Fontem, L. A. (2013). Developing an Integrated Management Approach for the Fruit Fly Dacus punctatifrons on Tomatoes. Am. J. Exp. Agric., 3 (3): 470-481.

[24] Fontem, D. A., Songwalang, A. T., Berinyuy, J. E., \& Schippers, R. R. (2003). Impact of fungicide applications for late blight management on huckleberry yields in Cameroon. Afr. Crop Sci. J., 11 (3): 163-170.

[25] Zettler, J. A., Mateer, S. C., Link-Pérez, M. A., Bailey, J., Demars, G., \& Ness, T. (2016). To Key or Not to Key: A New Key to Simplify \& Improve the Accuracy of Insect Identification. Am. Biol. Teach., 78 (8): 626-633.

[26] Albrecht, A. C. (2017). Illustrated identification guide to the Nordic aphids feeding on Conifers (Pinophyta) (Insecta, Hemiptera, Sternorhyncha, Aphidomorpha). Eur. J. Taxon., 338: $1-160$.

[27] Brailovsky, H. (2014). Illustrated key for identification of the species included in the genus Leptoglossus (Hemiptera: Heteroptera: Coreidae: Coreini: Anisoscelini), and descriptions of five new species and new synonyms. Zootaxa, 3794 (3): 143-178.

[28] Dirsh, V. M. (1965). The African genera of Acridoidea. Cambridge University Press for the Anti-Locust Research Center, London, xiii + , Pp. 579.

[29] Lecoq, M. (2010). Taxonomie et systématique des acridiens et principales espèces d'Afrique de l'Ouest. CIRAD, UPR Acridologie, Montpellier, France, Pp. 106.

[30] Freeman, P., \& Lane, R. P. (1985). Bibionid and Scatopsid flies. Diptera; Bibionidae and Scatopsidae (Handbooks for the Identification of British Insects 9/7). Royal Entomological Society, London, UK, Pp. 74.

[31] Kevan, D. K., \& McHsiung, C. C. (1985). The tropical and southern African species of Pyrgomorpha Audinet-Serville, 1838, other than the P. conica-group (Orthoptera: Acridoidea: Pyrgomorphidae). J. Entomol. Soc. South Africa, 48: 49-102.

[32] Tronquet, M. (2014). Catalogue des Coléoptères de France. Association Roussillonnaise d'Entomologie, Perpignan. Supplément au Tome XXIII-R. A. R. E., Pp. 1052.

[33] Gourmel, C. (2014). Catalogue illustré des principaux insectes ravageurs et auxiliaires des cultures de Guyane. Coopérative BioSavane, Guyane, Pp. 77. 
[34] Riley, E., Clark, S., \& Seeno, T. (2003). Catalog of leaf beetles of America north of Mexico (Coleoptera: Megalopodidae, Orsodacnidae and Chrysomelidae, excluding Bruchinae). Coleopterists Society. Special publication / Coleopterists Society, no. 1, Pp. 290.

[35] Shimat, V. J., Chong, J.-H., Campbell, B., Kunkel, B., Lauderdale, D., Jones, S., Gill, S., Chen, Y., Schultz, P., Held, D., Hale, F., Dale, A., Vafaie, E., Hudson, W., Gilrein, D., \& Del, Pozo-Valdivia, A. (2021). Current Pest Status and Management Practices for Systena frontalis (Coleoptera: Chrysomelidae) in Ornamental Plants in the Eastern United States: An Online Survey. J. Integr. Pest Manag., 12 (1): 17; $1-10$.

[36] Mahr, D. L. (2005). Redheaded flea beetle. Wisconsin Cranberry Crop Library: Insect Profiles. Available from https://fruit.webhosting.cals.wisc.edu/wp-content/uploads/sites/36/2011/05/Redheaded-Flea-Beetle.pdf).

[37] Lauderdale, D. (2017). Red-headed flea beetle biology and management. Winter 2017, Nursery and Landscape Notes 35. Available from https://wilson.ces.ncsu.edu/wpcontent/uploads/2017/02/2017-Nursery-Landscape-NotesRHFB-Article.pdf?fwd=no).

[38] Cloyd, R. A., \& Herrick, N. J. (2018). Red headed flea beetle. Kansas State University Agricultural Experiment Station and Cooperative Extension Service, MF3225. (https://www.bookstore.ksre.ksu.edu/pubs/MF3225.pdf).

[39] Jaffe, B., Rink, S., \& Guedot, C. (2021). Life History and Damage by Systena frontalis F. (Coleoptera: Chrysomelidae) on Vaccinium macrocarpon Ait. J. Insect Sci., 21 (1): 1-8.

[40] Ritter, C., \& Richter, E. (2013). Control methods and monitoring of Agriotes wireworms (Coleoptera: Elateridae). J. Plant Dis. Prot., 120: 4-15.

[41] Jakubowska, M., Bocianowski, J., \& Nowosad, K. (2018). Seasonal Fluctuation of Agriotes lineatus, A. obscurus and $A$. sputator Click Beetles Caught using Pheromone Traps in Poland. Plant Protect. Sci., 54 (2) 2: 118-127.

[42] Parker, W. E., \& Howard, J. J. (2001). The biology and management of wireworms (Agriotes spp.) on potato with particular reference to the U.K. Agric. For. Entomol., 3: 85-98.

[43] Evans, A. V. (2014). Beetles of Eastern North America. Princeton University Press. Princeton, New Jersey, Pp. 560.

[44] Orozco, J., \& Philips, T. K. (2010). Phylogenetic analysis of the American genus Euphoria and related groups based on morphological characters of adults (Coleoptera: Scarabaeidae: Cetoniinae: Cetoniini). Insect Syst. Evol., 41: 39-54.

[45] Benyahia, Y., Soldati, F., Rohi, L., Valladarès, L., Maatouf, N., Courtin, O., El, Antry, S., \& Bruste, H. (2015). First survey of darkling beetles (Coleoptera, Tenebrionidae) of Talassemtane National Park, Western Rif, Morocco. Check List., 11 (5): 1-9.

[46] Merkl, O. (2004). On taxonomy, nomenclature, and distribution of some Palaearctic Lagriini, with description of a new species from Taiwan (Coleoptera: Tenebrionidae). Acta Zool. Acad. Sci. Hung., 50 (4): 283-305.

[47] Prisniy, A. V., Merkl, O., Nabozhenko, M. V., \& Tsurikov, M. N. (2015). To the knowledge of the genus Lagria Fabricius, 1755 (Coleoptera: Tenebrionidae) of south and east of the Central Russian Upland. Caucasian Entomological Bull., 1 (2):
$357-362$.

[48] Schmitt, M., \& Rönn, T. (2011). Types of geographical distribution of leaf beetles (Chrysomelidae) in Central Europe. Zookeys, 157: 131-158.

[49] Gelhaus, J. K. (2005). The Crane-Fly Tipula (Tipula) oleracea (Diptera: Tipulidae). Reported From Michigan; A New Pest of Turfgrass in Eastern North America. Gt. Lakes Entomol., 38 (1): 97-99.

[50] Jandricic, S. E., Mattson, N. S., Wraight, S., \& Sanderson, J. P. (2014). Within-Plant Distribution of Aulacorthum solani (Hemiptera: Aphididae), on Various Greenhouse Plants With Implications for Control. J. Econ. Entomol., 107 (2): 697-707.

[51] Maharani, Y., Hidayat, P., Rauf, A., \& Maryana, N. (2018). New records of aphid species Subfamily Aphidinae (Hemiptera: Aphididae) in West Java, Indonesia. Biodiversitas, 19 (2): 510-515.

[52] Villalobos, Muller, W., Perez, Hidalgo, N., Mier, Durante, M. P., \& Nieto, Nafría, J. M., (2010). Aphididae (Hemiptera: Sternorrhyncha) from Costa Rica, with new records for Central America. Bol. Asoc. Esp. Entomol., 34 (1-2): 145-182.

[53] Sridhar, J., Kumari, N., Venkateswarlu, V., Bhatnagar, A., Malik, K., Sharma, S., \& Chakrabarti, S. (2020). Macrosiphum euphorbiae: A new aphid vector (Aphididae: Hemiptera) of PVY o and PLRV on potato from north western hills of India. J. Entomol. Zool. Stud., 8 (2): 1341-1344.

[54] Srinivasan, R., \& Alvarez, J. M. (2011). Specialized Host Utilization of Macrosiphum euphorbiae on a Nonnative Weed Host, Solanum sarrachoides, and Competition With Myzus persicae. Environ. Entomol., 40 (2): 350-356.

[55] Sidauruk, L., \& Sipayung, P. (2018). Population of Myzus persicae (Sulzer) and insect diversity on intercropping potatoes with other plants which planting at different time. IOP Conf. Ser. Earth Environ. Sci., 205 (1): 012018.

[56] Chasen, E. M., Dietrich, C., Backus, E. A., \& Cullen, E. M. (2014). Potato Leafhopper (Hemiptera: Cicadellidae) Ecology and Integrated Pest Management Focused on Alfalfa. J. Integr. Pest Manag., 5 (1): 1-8.

[57] Couilloud, R. (1989). Hétéroptères déprédateurs du cotonnier en Afrique et à Madagascar (Pyrrhocoridae, Pentatomidae, Coreidae, Alydidae, Rhopalidae, Lygaeidae). Coton et fibres tropicales, 44 (3): 185-226.

[58] Joda, A. O., Ewete, F. K., \& Pitan, O. O. R. (2014). Evaluation of Damage Induced by Aspavia armigera Fabricius on Different Rice (Oryza sativa Linn.) Varieties. J. Agric. Sci., $6(11): 30-36$.

[59] Joda, A. O. 2019. Developmental biology of Aspavia armigera (Fabricius, 1775) (Hemiptera: Pentatomidae) on rice (Oryza sativa L.) (Poaceae) and three other hosts in Nigeria. Pol. J. Entomol., 88 (4): 349-361.

[60] Panizzi, A. R. (2008). Southern green stink bug, Nezara viridula (L.) (Hemiptera: Heteroptera: Pentatomidae), Pp. 3471-3471. In J. L. Capinera (ed.), Encyclopedia of Entomology, Springer, Heidelberg.

[61] de, Santana, Souza, E., Lopes, Baldin, E. L., da, Silva, J. P. G. F., \& Lourenção, A. L. (2013). Feeding preference of Nezara viridula (Hemiptera: Pentatomidae) and attractiveness of soybean genotypes. Chil. J. Agric. Res., 73 (4): 351-357. 
[62] Popov, G. B., FishpooL, L. D. C., \& Rowell, C. H. F. (2019). A review of the Acridinae s. str. (Orthoptera: Acridoidea: Acrididae) of eastern Africa with taxonomic changes and description of new taxa. J. Orthoptera Res., 28 (1): 37-105.

[63] Kekeunou, S., Mbeng, D., Ngoute, C., \& Wandji, A. (2015). Morphology, development and reproduction of Pyrgomorpha vignaudii (Orthoptera: Pyrgomorphidae). Entomol. Res., 45: 58-70.

[64] Yetchom-Fondjo, J. A., Kekeunou, S., Kenne, M., Missoup, A D., \& Sheng-Quan, X. (2020). Diversity, abundance and distribution of grasshopper species (Orthoptera: Acrididea) in three different types of vegetation with different levels of anthropogenic disturbances in the Littoral Region of Cameroon. J. Insect Biodivers., 14 (1): 16-33.

[65] Panagiotopoulou, H., Baca, M., Baca, K., Sienkiewicz, P., Ślipinśki, P., \& Żmihorski, M. (2016). Genetic identification of a non-native species introgression into wild population of the field cricket Gryllus campestris (Orthoptera: Gryllidae) in Central Europe. Eur. J. Entomol., 113: 446-455.

[66] Kazemi, M. H., Jafari, S., Lotfalizadeh, H., \& MashhadiJafarloo, M. (2013). Wing dimorphism of European mole cricket Gryllotalpa gryllotalpa (L.) (Orthoptera: Gryllotalpidae) in the north-west of Iran. North West J. Zool., 9 (1): 45-50.

[67] Broza, M., Blondheim, S., \& Nevo, E. (2002). New species of mole crickets of the Gryllotalpa gryllotalpa group (Orthoptera: Gryllotalpidae) from Israel, based on morphology, song recordings, chromosomes and cuticular hydrocarbons, with comments on the distribution of the group in Europe and the Mediterranean region. Syst. Entomol., 23 (2): 125-35.

[68] Mally, R., Korycinska, A., Agassiz, D. J. L., Hall, J., Hodgetts, J., \& Nuss, M. (2015). Discovery of an unknown diversity of Leucinodes species damaging Solanaceae fruits in subSaharan Africa and moving in trade (Insecta, Lepidoptera, Pyraloidea). Zookeys, 472: 117-162.

[69] Brailovsky, H., \& van, der, Heyden, T. (2019). New distributional notes and key to the known species of Leptoglossus Guérin-Méneville from Guatemala (Heteroptera: Coreidae: Coreinae: Anisoscelini). Rev. Chil. Entomol., 45 (1): 175-180.

[70] Sharif, T., Irum, W., Asad, B., Ayesha, S., Maryam, A., \& Sohail, A. (2020). Taxonomic studies of family Pentatomidae (Hemiptera) four genera from district Faisalabad Punjab Pakistan with taxonomic keys. J. Entomol. Zool. Stud., 8 (1): 1338-1344.

[71] Dzokou, V. J., Lontchi, Fofe, N., Kamgaing, Kouam, B. H., Yaouba, A., \& Tamesse, J. L. (2021). Fauna Pests Infesting Pepper (Piper nigrum L.) in Penja-Cameroon. Am. J. Entomol., 5 (2): 32-38.

[72] Rice, W. (1989). Analyzing tables of statistical tests. Evolution 43 (1): 223-225.

[73] Schluter, D. A. (1984). A variance test for detecting species associations, with some example applications. Ecology, 65 (3): 998-1005.

[74] Chao, A., Chadzon, R. L., Colwell, R. K., \& Shen, T.-J. (2005). A new statistical approach for assessing similarity of species composition with incidence and abundance data. Ecol. Lett., 8: 148-159.
[75] Biawa-Kagmegni, M., Foguieng-Saha, A. D., GuetsopNgouadjie, R. P., Tsekane, S. J., Fouelifack-Nintidem B. Moumite Mohamed, B., Yetchom-Fondjo, J. A., NgamaleuSiewe, B., Kenne, E. L., Tuekam Kowa P. S., Fantio R. M., Yomon, A. K., Mbenoun Masse, P. S., Kenne, M., \& Fomena, A. (2021). Ants community structure in the urban and the city suburbs areas of Douala (Littoral-Cameroon). J. Insect Biodivers., 025 (2): 033-059.

[76] McGill, B. J., Etienne, R. S., Gray, J. S., Alonso, D., Anderson, M. J., Benecha, H. K., Dornelas, M., Enquist, B. J., Green, J. L., He, F., Hurlbet, A. H., Magurran, A. E., Marquet, P. A., Maurer, B. A., Ostling, A., Soykan, C. U., Ugland, K. I., \& White, E. P. (2007). Species abundance distributions: moving beyond single prediction theories to integration within an ecological framework. Ecol. Lett., 10 (10): 995-1015.

[77] Johnson, J. B., \& Omland, K. S. (2004). Model selection in ecology and evolution. Trends Ecol. Evol., 19 (2): 101-108.

[78] R Core Team, (2018). R: A language and environment for statistical computing. R Foundation for Statistical Computing, Vienna, Austria. Available from http://www.R-project.org/.

[79] Wilson, J. B. (1991). Methods for fitting dominance/diversity curves. J. Veg. Sci., 2 (1): 35-46.

[80] Iganaki, H. (1967). Mise au point de la loi de Motomura et essai d'une écologie évolutive. Vie et Milieu, 18: 153-166.

[81] Li, W. (2002). Zipf's Law Everywhere. Glottometrics, 5: 14-21.

[82] Zipf, G. K. (1965). Human Behaivour and the Principle of Least Effort: An introduction to human ecology. ( $2^{\text {nd }}$ edition $)$, Hafner, New York, NY, USA, Pp. 573.

[83] Le, D.-H., Pham, C.-K., Nguyen, T. T. T., \& Bui, T. T. (2012) Parameter extraction and optimization using LevenbergMarquardt algorithm, Pp. 434-437. In Proceedings of 2012 IEEE conference. Fourth International Conference on Communications and Electronics (ICCE), Hanoi University of Science and Technology, Hanoi (Vietnam).

[84] Murthy, Z. V. P. 2014. Nonlinear Regression: LevenbergMarquardt Method, Pp. 1-3. In E. Drioli, \& L. Giorno, (ed.s), Encyclopedia of Membranes. Springer-Verlag, Berlin, Heidelberg.

[85] Frontier, S. (1987). Applications of Fractal Theory to Ecology, Pp. 335-378. In P. Legendre, \& L. Legendre (eds.). Developments in Numerical Ecology. NATO ASI Series book series (volume 14). Springer, Berlin, Heidelberg.

[86] Bach, P., Amanieu, M., Lam-Hoai, T., \& Lasserre, G. (1988). Application du modèle de distribution d'abondance de Mandelbrot a l'estimation des captures dans l'étang de Thau. J. Cons. Int. Explor. Mer, 44: 235-246.

[87] Dias, R. K. S., \& Kosgamage, K. R. K. A. (2012). Occurrence and Species Diversity of Ground-Dwelling Worker Ants (Family: Formicidae) in Selected Lands in the Dry Zone of Sri Lanka. J. Sci. Univ. Kelaniya, 7: 55-72.

[88] Uno, S., Cotton, J., \& Philpott, S. M. (2010). Diversity, abundance, and species composition of ants in urban green spaces. Urban Ecosyst., 13: 425-441.

[89] Solar, R. R. C., Barlow, J., Andersen, A. N., Schoereder, J. H., Berenguer, E., Ferreira, J. N., \& Gardner, T. A. (2016). Biodiversity consequences of land-use change and forest disturbance in the Amazon: A multi-scale assessment using ant communities. Biol. Conserv., 197: 98-107. 
[90] Holway, D. A., Lach, L., Suarez, A. V., Tsutsui, N. D., \& Case, T. J. (2002). The causes and components of ant invasions. Annu. Rev. Ecol. Syst., 33: 181-233.

[91] Adja, N. A., Danho, M., Alabi, T. A. F., Gnago, A. J., Zimmer, J. Y., Francis, F., Kouassi, P., Baudoin, J. P., \& Zoro Bi, I. A. (2014). Entomofauna associated with African oleaginous cucurbits (Lagenaria siceraria Molina (Standl. 1930) and Citrullus lanatus Thumb (Matsum \& Nakai 1916)) and impact of pests on production. Int. J. Entomol., 50 (3-4): 301-310.

[92] Ofori, E. S. K., Afful, N., Quartey, E. K., Osae, M., \& Amoatey, H. M. (2015). Preliminary Ecological Studies of Insect Species Associated with Different Accessions of Eggplant (Solanum melongena L.) in Southern Ghana. J. Agric. Ecol., 4 (4): 199-210.

[93] Saguez, J., Latraverse, A., De, Almeida, J., van, Herk, W. G, Vernon, R. S., Légaré, J.-P., Moisan-de, Serre, J., Fréchette, M. \&, Labrie, G. (2017). Wireworm in Quebec field crops: specific community composition in North America. Environ. Entomol., 46 (4): 814-825.

[94] Kenne, M., Djiéto-Lordon, C., Orivel, J., Mony, R., Fabre, A., \& Dejean, A. (2003). Influence of Insecticide Treatments on Ant-Hemiptera Associations in Tropical Plantations. J. Econ. Entomol., 96 (2): 251-258.

[95] Munyaneza, J. E., Jensen, A. S., Hamm, P. B., \& Upton, J. E. (2008). Seasonal occurrence and abundance of beet leafhopper in the potato growing region of Washington and Oregon Columbia Basin and Yakima Valley. Am. J. Potato Res., 85: 77-84.

[96] Nasruddin, A., Fattah, A., Baco, M. S., \& Said, A. E. (2014). Potential damages, seasonal abundance and distribution of Empoasca terminalis Distant (Homoptera: Cicadellidae) on soybean in South Sulawesi. Indones. J. Entomol., 11 (2): 93102 .

[97] Labrie, G., \& De, Almeida J. (2011). La tipule des prairies dans les grandes cultures au Québec. Antennae, 18 (2): 7-9.

[98] Talekar, N. S., Open'a, R. T., \& Hanson, P. (2006). Helicoverpa armigera management: a review of AVRDC's research on host plant resistance in tomato. Crop Prot., 25 (5): 461-467.

[99] Bindu, S. P., Pramanik, A., \& Padhi, G. K. (2015). Studies on Biology and physical measurements of shoot and fruit borer (Leucinodes orbonalis Guenee) of Brinjal in West Bengal, India. Glob. J. Biol. Agric. Health Sci., 4 (1): 215-219.
[100] Shirale, D., Patil, M., \& Parimi, S. (2017). Insecticide resistance in field populations of Leucinodes orbonalis (Lepidoptera: Crambidae) in India. Can. Entomol., 149 (3): 19.

[101] Naseem, R., Naureen, R., Elmo, K., Waqar, M., \& Shahla, N. (2020). Abundance and diversity of foliage insects among different Olericulture Crops. GSC Biol. Pharm. Sci., 10 (2): 062-069.

[102] Srinivasan, R. (2009). Insect and mite pests on eggplant: a field guide for indentification and management. AVRDC The World Vegetable Center, Shanhua, Taiwan, Pp. 64.

[103] Galante, E., \& Cartagena, M. C. (1999). Comparison of Mediterranean dung beetles (Coleoptera: Scarabaeoidea) in cattle and rabbit dung. Environmental Entomology 28 (3): 420-424.

[104] Komonen, A., \& Elo, M. (2017). Ecological response hides behind the species abundance distribution: Community response to low-intensity disturbance in managed grasslands. Ecol. Evol., 7 (20): 8558-8566.

[105] Lowe, S., Browne, M., Boudjelas, S., \& De, Poorter, M. (2000). 100 of theWorld's Worst Invasive Alien Species. A selection from the Global Invasive Species Database. The Invasive Species Specialist Group (ISSG) a specialist group of the Species Survival Commission (SSC) of the World Conservation Union (IUCN), Hollands Printing Ltd, New Zealand, Pp. 12.

[106] Ferreira, F. C., \& Petrere-Jr., M. (2008). Comments about some species abundance patterns: classic, neutral, and niche partitioning models. Braz. J. Biol., 68 (4, Suppl.): 1003-1012.

[107] McGlynn, T. P. (1999). The worldwide transfer of ants: geographical distribution and ecological invasions. J. Biogeogr., 26 (3): 535-548.

[108] Shea, K., \& Chesson, P. (2002). Community ecology theory as a framework for biological invasions. Trends Ecol. Evol., 17 (4): $170-176$.

[109] Babu, S. R., \& Subrahmanyam, B. (2010). Bio-potency of serine proteinase inhibitors from Acacia senegal seeds on digestive proteinases, larval growth and development of Helicoverpa armigera (Hübner). Pestic. Biochem. Physiol., 98 (3): 349-358. 